\title{
$\Delta$ Np63 Regulates Stem Cell Dynamics in the Mammalian Olfactory Epithelium
}

\author{
Adam Packard, ${ }^{1,3}$ Nikolai Schnittke, ${ }^{1,2,3 *}$ Rose-Anne Romano, ${ }^{4}$ Satrajit Sinha, ${ }^{4}$ and James E. Schwob ${ }^{1,3}$ \\ ${ }^{1}$ Program in Cell, Molecular and Developmental Biology and ${ }^{2}$ Medical Scientist Training Program, Sackler School of Graduate Biomedical Sciences, and \\ ${ }^{3}$ Department of Anatomy and Cell Biology, School of Medicine, Tufts University, Boston, Massachusetts 02111, and ${ }^{4}$ Department of Biochemistry, State \\ University of New York at Buffalo, Buffalo, New York 14203
}

The ability of the olfactory epithelium (OE) to regenerate after injury is mediated by at least two populations of presumed stem cellsglobose basal cells (GBCs) and horizontal basal cells (HBCs). Of the two, GBCs are molecularly and phenotypically analogous to the olfactory progenitors of the embryonic placode (OPPs). In contrast, HBCs are a reserve stem cell population that appears later in development and requires activation by severe epithelial damage before contributing to epithelial reconstitution. Neither HBC emergence nor the mechanism of activation after injury is understood. Here we show that the transcription factor p63 (Trp63), which is expressed selectively by adult HBCs, is required for HBC differentiation. The first evidence of $\mathrm{HBC}$ differentiation is the expression of $\mathrm{p} 63$ by cells that closely resemble embryonic OPPs and adult GBCs by morphology and expression of the transcription factors Sox2, Ascl1, and Hes1. HBC formation is delayed in Ascll knock-out OE and is completely abrogated in p63-null mice. Strikingly, other cell types of the OE form normally in the $\mathrm{p} 63$ knock-out OE. The role of $\mathrm{p} 63$ in HBC differentiation appears to be conserved in the regenerating rat $\mathrm{OE}$, where $\mathrm{HBCs}$ disappear and then reappear after tissue lesion. Finally, p63 protein is downregulated in HBCs activated by lesion to become multipotent progenitor cells. Together, our data identify a novel mechanism for the generation of a reserve stem cell population and suggest that a p63-dependent molecular switch is responsible for activating reserve stem cells when they are needed.

\section{Introduction}

Adult stem cells are responsible for the maintenance and repair of self-renewing tissues throughout life. In some tissues, several progenitor populations are set aside during development to contribute to tissue maintenance and/or repair (Ito et al., 2007; Leung et al., 2007; Carlén et al., 2009). Stem cells that contribute to repair as opposed to maintenance often appear dormant in adult tissues, but can be activated by injury to generate multiple cell types (Ito et al., 2007; Carlén et al., 2009). Here we examine the dynamics of such a reserve stem cell population in the mammalian olfactory epithelium (OE).

Two broad basal cell populations with characteristics of stem cells have been identified in the adult OE. (1) Globose basal cells (GBCs) are situated just basal to olfactory sensory neurons (OSNs) and constitute a functionally heterogeneous population. GBCs in the maturing and adult OE resemble the olfactory placode progenitor cells (OPPs) that give rise to the

\footnotetext{
Received Feb. 6, 2011; revised March 21, 2011; accepted April 22, 2011.

Author contributions: A.P., N.S., and J.E.S. designed research; A.P., N.S., and J.E.S. performed research; R.-A.R. and S.S. contributed unpublished reagents/analytic tools; A.P., N.S., and J.E.S. analyzed data; A.P., N.S., R.-A.R., S.S., and J.E.S. wrote the paper.

This work was supported by grants from the NIH: R01DC002167 to J.E.S. and F30DC011241 to N.S. We thank all the members of the Schwob lab, especially Richard Krolewski and Po Kwok Tse. We thank Cathy Linsenmeyer for assistance with the electron microscopy studies.

*A.P. and N.S. contributed equally to this work.

Correspondence should be addressed to Dr. James E. Schwob, Department of Anatomy and Cellular Biology, Tufts University School of Medicine, 136 Harrison Avenue, Boston, MA 02111. E-mail: jim.schwob@tufts.edu.

DOI:10.1523/JNEUROSCI.0681-11.2011

Copyright $\odot 2011$ the authors $\quad 0270-6474 / 11 / 318748-12 \$ 15.00 / 0$
}

OE during embryogenesis, with respect to transcription factor profile (Cau et al., 2000, 2002; Manglapus et al., 2004; Guo et al., 2010). Accordingly, clonal analysis following retroviral lineage tracing and transplantation after FACS purification show that GBCs encompass lineage-committed progenitors as well as lineage-uncommitted multipotent stem and/or progenitor cells (Goldstein et al., 1998; Huard et al., 1998; Jang et al., 2003; Chen et al., 2004). (2) Horizontal basal cells (HBCs) are arranged as a monolayer of flattened cells directly apposed and tightly adherent to the basal lamina. In contrast to GBCs, HBCs do not appear until late embryogenesis and do not form a complete differentiated monolayer until the second week after birth (Holbrook et al., 1995). However, genetic lineage tracing demonstrates that some HBCs are multipotent cells capable of giving rise to all cellular constituents of the epithelium after injury, suggesting that HBCs are a reserve stem cell population and contribute to tissue repair (Leung et al., 2007).

In skin and other stratified epithelia, the transcription factor p63 (a member of the p53 family) is highly expressed in the basal cell layer. Homozygous p63 mutant mice fail to form stratified epithelia due to a defect in progenitor cell generation and maintenance (Mills et al., 1999; Yang et al., 1999; Candi et al., 2007; McKeon and Melino, 2007). Among the genes directly regulated by $\mathrm{p} 63$ are the prototypic basal cell cytokeratins K5/K14 (Romano et al., 2009); molecules which mediate adhesion to the basal lamina, such as integrins (Carroll et al., 2006); components of signaling pathways including the Notch and Wnt pathways (Laurikkala et al., 2006; Romano et al., 2010; Yalcin-Ozuysal et al., 2010), and chromatin remodeling components (Keyes et al., 2011). 
Table 1. Antibodies and staining protocols used in this study

\begin{tabular}{|c|c|c|c|}
\hline Primary antibody & Source/Vendor & Protocol & Cell type(s) marked \\
\hline$R b \alpha-C K 14$ & Lab Vision & $(1: 500) \rightarrow$ fluor-D $\alpha \mathrm{Rb}$ & $\mathrm{HBCS}$ \\
\hline$R b \alpha-C K 18$ & Abcam & $(1: 300) \rightarrow$ fluor-D $\alpha \mathrm{Rb}$ & Sus and duct/gland cells \\
\hline Gt $\alpha$-mouse CD54 & R\&D Systems & $(1: 100) \rightarrow$ fluor-D $\alpha \mathrm{Gt}$ & $\mathrm{HBCS}$ \\
\hline Gt $\alpha$-Collagen type IV & Southern Biotechnology & $(1: 25) \rightarrow$ fluor-D $\alpha \mathrm{Gt}$ & Basal lamina \\
\hline$R b \alpha-G A P 43$ & Epitomics & $(1: 100) \rightarrow$ fluor-DaRb & Immature $>>$ mature Neurons \\
\hline$R b \alpha$-GFP & Abcam & $(1: 1,000) \rightarrow$ fluor-DaRb & GFP \\
\hline Rb $\alpha$-Hes1 & T. Sudo (Ito et al., 2000) (gift) & $(1: 10,000) \rightarrow$ TSA $\rightarrow$ fluor-SA & GBCs (Sus progenitors), Sus, duct/gland cells \\
\hline Mo $\alpha$-Mash1 (Ascl1) & BD Pharmingen & $(1: 2000) \rightarrow \mathrm{TSA} \rightarrow$ fluor-SA & GBCs (neuronal progenitors) \\
\hline Gt $\alpha-O M P$ & Wako (from Frank Margolis, Richmond, VA) & $(1: 120) \rightarrow$ fluor-D $\alpha \mathrm{Gt}$ & Mature OSNs \\
\hline Mo $\alpha-p 63$ & Santa Cruz Biotechnology & $(1: 200) \rightarrow$ fluor $-D \alpha M_{0}$ & HBCs, HBC progenitors, nascent HBCs. All p63 isoforms \\
\hline$R b \alpha-\Delta N p 63(R R 14)$ & S. Sinha (Romano et al., 2006) & $(1: 50) \rightarrow$ fluor-D $\alpha \mathrm{Rb}$ & $H B C S, H B C$ progenitors, nascent $H B C s$. Specific for $\triangle N p 63$ \\
\hline$R b \alpha-P G P 9.5$ & Ultraclone & $(1: 1200) \rightarrow$ fluor-D $\alpha \mathrm{Rb}$ & All neurons \\
\hline Gt $\alpha$-Sox2 & Santa Cruz Biotechnology & $(1: 80) \rightarrow b D \alpha G t \rightarrow$ fluor $-S A$ & Sus cells, HBCs, GBCs \\
\hline$R b \alpha-$ Sox2 & Cell Signaling Technology & $(1: 100) \rightarrow$ fluor-D $\alpha \mathrm{Rb}$ & Sus cells, HBCs, GBCs. Same pattern as Gt $\alpha$-Sox2 \\
\hline$R b \alpha-\operatorname{Sox} 9$ & Millipore & $(1: 500) \rightarrow$ fluor-D $\alpha \mathrm{Rb}$ & Duct/gland, microvillar cells \\
\hline Mo $\alpha$-Tu」1 & Covance & $(1: 100) \rightarrow$ fluor $-D \alpha M_{0}$ & Neuron-specific tubulin \\
\hline
\end{tabular}

A variety of fluorophores (fluors) were used: green, Alexa Fluor-488; red, Alexa Fluor-594 (epifluorescence) or Cy3 (confocal); blue, AMCA (7-amino-4-methylcoumarin-3-acetic acid). Alexa-conjugated secondary antibodies were used at 1:250. Cy3-conjugated reagents were used at 1:150 for directly conjugated secondary antibodies or 1:750 for TSA (Tyramide Signal Amplification Kit from Perkin Elmer). AMCA was used at 1:100. Rb, Rabbit; Mo, mouse; Gt, goat; $b$, biotinylated secondary antibody.

Here, we report that p63 is expressed in differentiating and mature HBCs and is required for their generation during development. We also demonstrate the sequential downregulation and reexpression of $\mathrm{p} 63$ during recovery of the adult epithelium from injury that substantiates a role for p63 in the cycle of $\mathrm{HBC}$ activation and return to dormancy.

\section{Materials and Methods}

Animal strains. Adult Sprague Dawley (Sprague Dawley) rats were purchased from Taconic. Wild-type C57BL/6 mice from Jackson Labs were used to analyze embryonic expression of p63. C57BL/6 mice were mated to $129 \mathrm{~S} 1 / \mathrm{Sv} 1 \mathrm{MJ}$ (Jackson Labs) to produce the $\mathrm{F} 1$ progeny used in methyl bromide (MeBr) lesion experiments. Generation of $\Delta$ Mash1GFP (Ascl1 KO) knock-in mice and B6.129S7-Trp63tm2Brd/J (Brdm2 p63 KO) mice has been described previously (Mills et al., 1999; Wildner et al., 2006). To generate $\Delta \mathrm{Np} 63^{\mathrm{GFP}}$ knock-in animals, we engineered a targeting construct containing genomic sequences located $5^{\prime}$ and $3^{\prime}$ to the $\Delta$ Np63-specific exon to facilitate homologous recombination. The EGFP gene was fused in-frame to the codon that is specific for the $\Delta \mathrm{N}$ isoform of the $p 63$ gene to preserve as closely as possible the endogenous regulation of $\Delta \mathrm{Np} 63$ at the transcriptional level. Additionally, a neomycin resistance gene (PGK-neo) flanked by FRT sites and the diphtheria toxin gene was used for selection in 129Sv embryonic stem (ES) cells. Two correctly targeted ES clones were identified by Southern blotting and PCR. The selection and expansion of the ES cell clones were performed by the Gene Targeting and Transgenic Core Facility at Roswell Park Cancer Institute. We used $\Delta \mathrm{Np} 63$ GFP ${ }^{\mathrm{ES}}$ cells to generate chimeras that were then bred to C57BL/6 mice to obtain germline transmission. The heterozygous $\Delta \mathrm{Np} 63{ }^{\mathrm{GFP}}$ offspring were subsequently crossed to generate homozygous $\Delta \mathrm{Np} 63^{\mathrm{GFP} / \mathrm{GFP}}$, $\Delta \mathrm{Np} 63^{\mathrm{GFP}}$, and wild-type mice for analysis. Details about the generation of the $\Delta \mathrm{Np} 63^{\mathrm{GFP}}$ knock-in animals and their detailed phenotypic characterization are described in a separate manuscript (R.-A. Romano, K. Smalley, and S. Sinha, unpublished observations). All protocols governing the use of vertebrate animals were approved by the Committee for the Humane Use of Animals at Tufts University School of Medicine, where the animals were housed and experiments were conducted.

Tissue processing for immunohistochemistry. Pregnant dams were killed by cervical dislocation. Embryos were harvested and staged based on crown-rump length and Theiler criteria. The embryos were immersion-fixed in $4 \%$ paraformaldehyde (PFA) overnight. Neonates [up to postnatal day 3 (P3)] were killed by rapid decapitation and immersion-fixed in 4\% PFA overnight. All rats and mice P10 and older were anesthetized with an intraperitoneal injection of a triple mixture of ketamine $(37.5 \mathrm{mg} / \mathrm{kg})$, xylazine $(7.5 \mathrm{mg} / \mathrm{kg})$, and acepromazine $(1.25 \mathrm{mg} / \mathrm{kg})$. Anesthetized animals were transcardially flushed with PBS and perfused with $4 \%$ PFA. After dissection, the tissue was postfixed in $4 \%$ PFA under vacuum and decalcified in saturated EDTA overnight. All tissue was cryoprotected in 30\% sucrose in PBS, embedded in OCT compound (Miles Inc.), and frozen in liquid nitrogen. Coronal sections $(8 \mu \mathrm{m})$ were generated on a Leica cryostat, mounted on "Plus" slides (Fisher Scientific), and stored at $-20^{\circ} \mathrm{C}$ until needed.

Reverse transcriptase-PCR. Cells of the olfactory mucosa were dissociated and sorted by FACS for viability on the basis of propidium iodide exclusion (Chen et al., 2004). RNA was isolated from $10^{6}$ viable cells using the Zymo Research DNA-free RNA purification kit. To generate cDNA, 50 ng of RNA were reverse transcribed using SuperScript III reverse transcriptase (RT) (Invitrogen). A no-RT control was also performed with $50 \mathrm{ng}$ of RNA. cDNA was subjected to PCR using primers and conditions as described previously (Nakamuta and Kobayashi, 2007).

Immunohistochemistry. Primary antibody dilutions and the details of their working conditions and detection are listed in Table 1. Tissue sections were rinsed in PBS to remove OCT, puddled with citrate buffer, and steamed for $10 \mathrm{~min}$ in a commercial food steamer. Sections were blocked with $10 \%$ donkey serum $/ 5 \%$ nonfat dry milk/4\% BSA $/ 0.1 \%$ Triton $\mathrm{X}-100$ in PBS and incubated overnight in primary antibody. The following day the staining was visualized using an array of methods as indicated in Table 1. Unless otherwise indicated, blue represents the nuclear counterstain DAPI.

Image processing and quantification. Stained sections were imaged on a Zeiss 510 confocal microscope in multitracking mode or on a Nikon $800 \mathrm{E}$ epifluorescent microscope with a Spot RT2 digital camera. Image preparation, assembly and analysis were performed in Adobe Photoshop CS2. In the vast majority of photos, only balance, contrast, and evenness of the illumination were altered. In cases where tyramide signal amplification was used to visualize bound antibody (Ascl1 and Hes1 staining), a median noise filter of 2 pixels or less was applied to images. This filter reduces nonspecific background speckling smaller than the filter setting and does not alter those features (nuclear and cytoplasmic) specific to the antibody staining. For Figure $2 B$ (see below), low-magnification images were taken with the Spot RT2 camera and assembled to encompass the entire tissue. The staining was highlighted using standard Photoshop tools.

Cell types were counted by direct observation with the epifluorescent microscope. A low-magnification image was used to measure the length of OE counted. Three animals (at least 3 sections/animal) were counted per time point examined, and the data were analyzed by two-way 
A
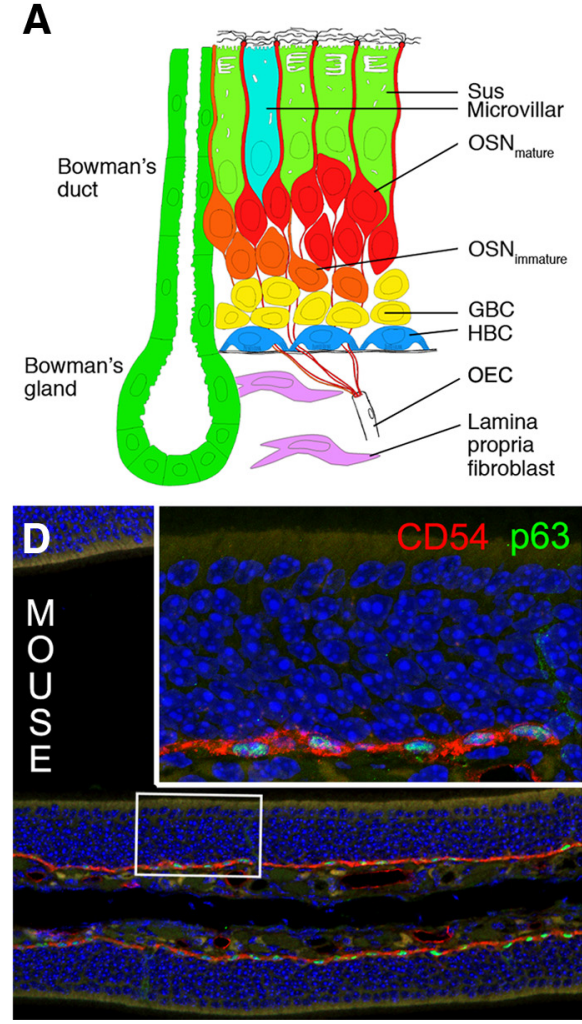
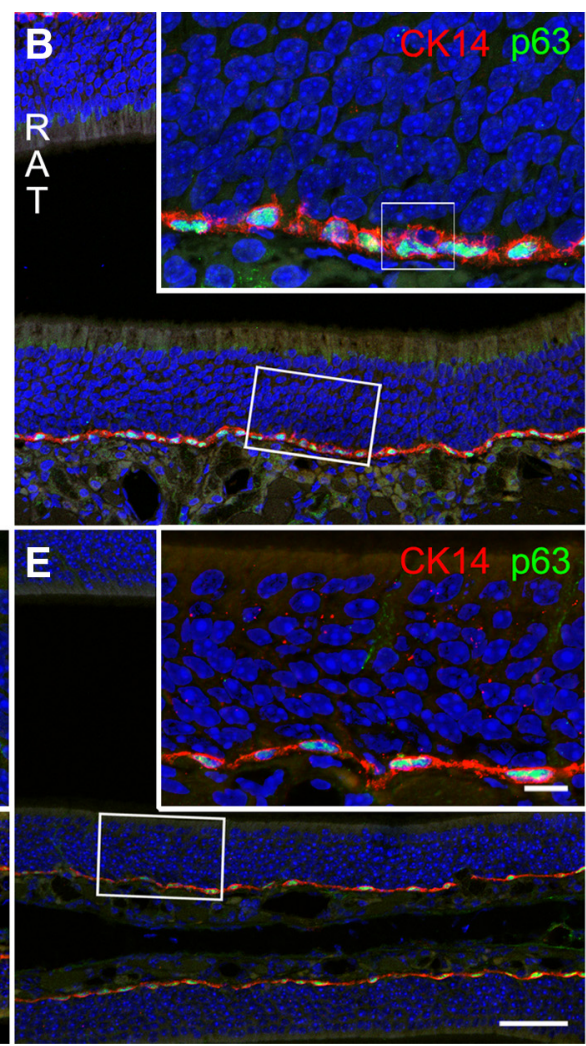

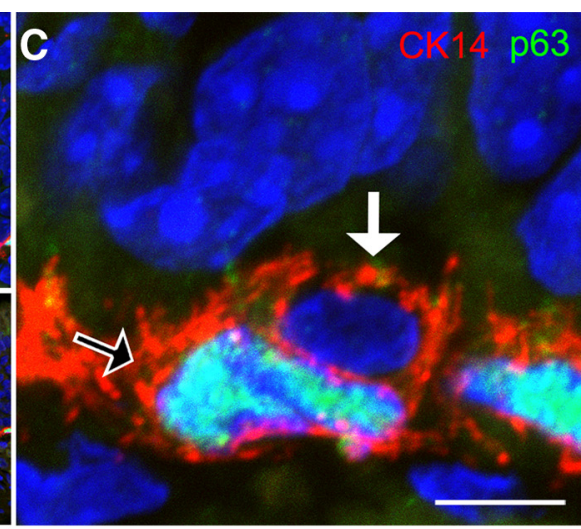

F

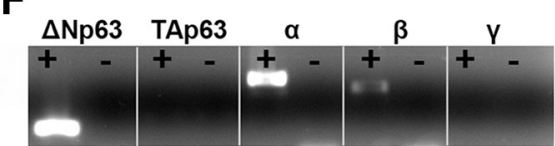

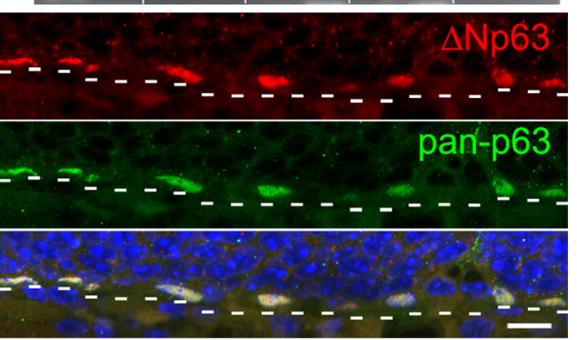

Figure 1. $A-F, \triangle N p 63$ is expressed by $\mathrm{HBC}$ of the adult $\mathrm{OE}$ of rat $(\boldsymbol{B}, \boldsymbol{C})$ and mouse $(\boldsymbol{D}-\boldsymbol{F})$. Boxed areas are shown at higher magnification in the insets. $\boldsymbol{A}$, Schematic of the cell types present in

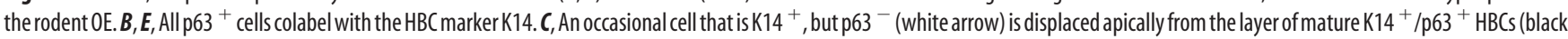
arrow). D, All p63 ${ }^{+}$cells colabel with CD54, another HBC marker. $F$, Semiquantitative RT-PCR (top) reveals that $\Delta$ Np63 is the only detectable $5^{\prime}$ isoform of p63 expressed in the $0 E$. The $\alpha$ and, to a lesser extent, $\beta$ isoforms, but not the $\gamma$ isoform, are the primary $3^{\prime}$ isoforms. Immunohistochemistry (bottom) of anti- $\Delta$ Np63 colocalization with anti-pan-p63. Dotted line represents the basal lamina. Scale bars: $(\boldsymbol{A}, \boldsymbol{B}, \boldsymbol{D}-\boldsymbol{F}), 50 \mu \mathrm{m}$; inset, $10 \mu \mathrm{m} ;(\boldsymbol{C}), 5 \mu \mathrm{m}$.

ANOVA using GraphPad Prism software. Mean values and SEM are reported.

5-Ethynyl-2'-deoxyuridine administration and processing. 5-Ethynyl$2^{\prime}$-deoxyuridine (EdU) $(80 \mathrm{mg} / \mathrm{g})$ (Invitrogen) was administered by subcutaneous injection to animals or pregnant dams. Two hours after injection, tissue was processed as above. For visualization of EdU incorporation, sections were permeabilized with $0.5 \%$ Triton X-100 in PBS, and treated with azide-594 containing Click-iT Reaction Cocktail (Invitrogen) for $30 \mathrm{~min}$. After 3 washes in 3\% BSA in PBS, sections were steamed and stained for $\mathrm{p} 63$ as above.

Electron microscopy. The heads from $\mathrm{P} 0 \mathrm{p} 63^{+/+}$and $\mathrm{p} 63^{-1-}$ pups were immersion-fixed overnight in EM fix $(4 \%$ PFA $+3 \%$ glutaraldehyde in $0.1 \mathrm{~m}$ cacodylate buffer, $\mathrm{pH}$ 7.3). The olfactory tissue was then sectioned at $1 \mathrm{~mm}$ using a vibratome (Leica) and collected in cacodylate buffer. Sections were processed according to previously published protocols (Holbrook et al., 1995; Kubilus and Linsenmayer, 2010) and viewed on a Philips CM-10 transmission electron microscope at $80 \mathrm{kV}$.

$\mathrm{MeBr}$ lesion. Twelve-week-old F1 $(\mathrm{C} 57 \times 129)$ male mice were exposed to $180 \mathrm{ppm} \mathrm{MeBr}$ gas in pure air for $8 \mathrm{~h}$ (Chen et al., 2004). Sprague Dawley rats at $300 \mathrm{~g}$ body weight were exposed to $330 \mathrm{ppm} \mathrm{MeBr}$ gas in pure air for $6 \mathrm{~h}$ (Schwob et al., 1995).

\section{Results}

\section{p63 marks phenotypically differentiated $\mathrm{HBCs}$}

The OE is a pseudostratified neuroepithelium that consists of OSNs, sustentacular (Sus) cells, duct/gland assemblies, microvillar cells, and a set of morphologically and functionally heterogeneous basal cells including HBCs and GBCs (Graziadei and Graziadei, 1979). The lamina propria of the olfactory mucosa contains olfactory ensheathing cells that surround the axon fascicles of the OSNs as well as a heterogeneous population of fibro- blasts, some of which might function as mesenchymal stem cells (Tomé et al., 2009; Delorme et al., 2010) (Fig. 1A). In adult mouse and rat $\mathrm{OE}$ we find that anti-p63 antibodies label the nuclei of basal cells that are immediately apposed to the basal lamina; the $\mathrm{p} 63^{+}$cells are flat, have scant cytoplasm, and colabel with the HBC markers K14 and CD54 [ICAM-1 (intercellular adhesion molecule 1)] (Fig. 1B,D,E; data not shown). Rarely, some of the $\mathrm{K}_{14}{ }^{+}$HBCs do not contain detectable p63 (Fig. 1C). Such p $63^{-} / \mathrm{K}_{14}{ }^{+}$cells represent $\sim 4 \%$ (8 of 201 ) of the total $\mathrm{K}_{14}{ }^{+}$cells in the rat and $<1 \%$ ( 2 of 235 ) in the mouse.

The $p 63$ gene encodes two sets of $\mathrm{N}$-terminal isoforms driven by alternate promoters and 3 different $\mathrm{C}$-terminal isoforms $(\alpha, \beta$, and $\gamma$ ) generated by alternative splicing (Yang et al., 1998; Ghioni et al., 2002; Candi et al., 2007). The prevalent N-terminal isoforms present in the basal cells of most stratified epithelia are the $\Delta \mathrm{Np} 63$ forms, which lack a transcriptional transactivation domain at the $5^{\prime}$ end of the gene (Candi et al., 2006). The TAp63 isoforms, which contain the transactivation domain, control CNS development (playing a role in neuronal apoptosis) and female germline maintenance (Jacobs et al., 2005; Suh et al., 2006). Semiquantitative RT-PCR of RNA isolated from murine whole olfactory mucosa indicates that $\Delta \mathrm{Np} 63 \alpha$ and $-\beta$ are the prevalent isoforms of p63 expressed in the OE; under the same conditions, no TA- or $\gamma$-isoforms were detected. Immunolabeling with a $\Delta$ Np63-specific antibody (Romano et al., 2006) is completely coextensive with pan-p63 antibody staining in the HBCs (Fig. $1 F$ ), while a TAp63-specific antibody did not generate any nuclear signal in the OE (Romano et al., 2009). 
A
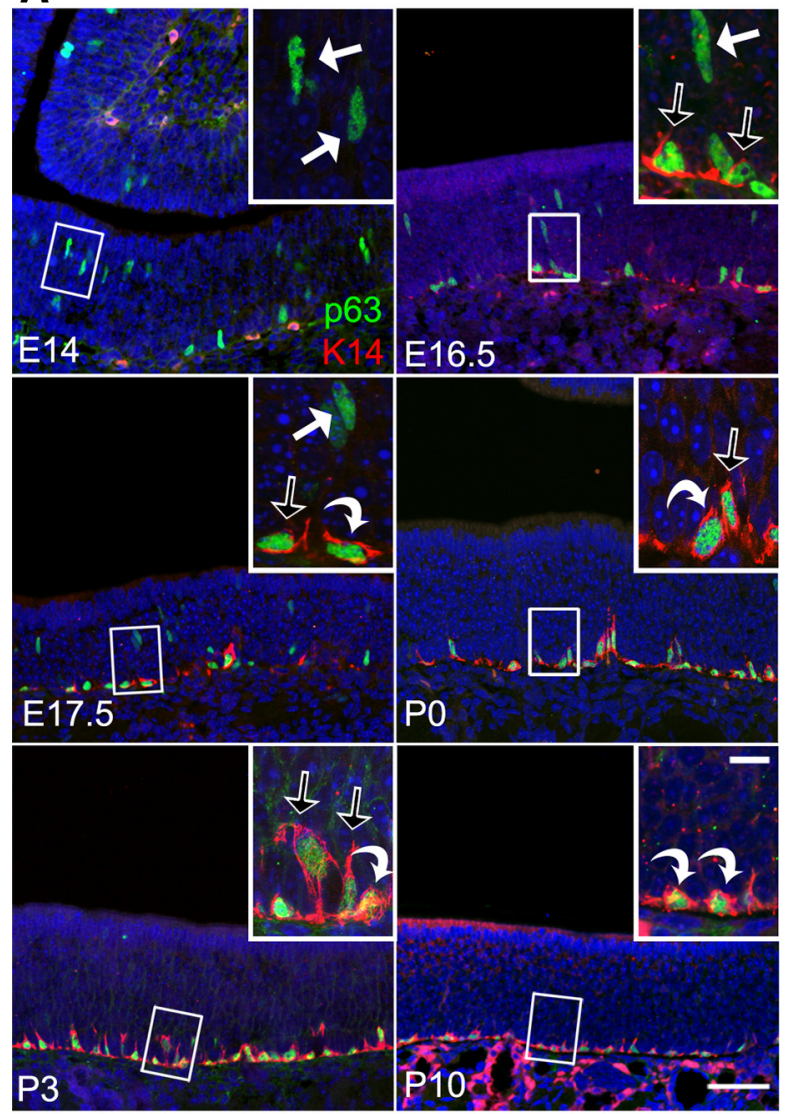
Po

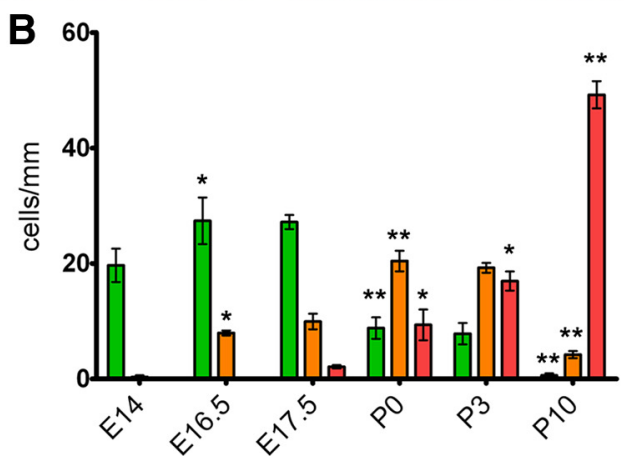

$\square$ HBC Progenitors (p63 ${ }^{+} / \mathrm{K}^{-} 4^{-}$)

$\square$ Nascent HBCs (p63 ${ }^{+} / \mathrm{K} 14^{\mathrm{lo})}$

Mature HBCs $\left(\mathrm{p} 63^{+} / \mathrm{K} 14^{+}\right)$

Figure 2. $p 63$ expression anticipates $\mathrm{HBC}$ differentiation. $\boldsymbol{A}$, Developmental expression of immunopositive $p 63$ in the mouse $0 \mathrm{E}$. Apical $\mathrm{p} 63^{+} / \mathrm{K} 14^{-}$cells (HBC progenitors, white arrows) are first seen at E14 and persist into the early postnatal period. By E16.5, some p $63{ }^{+}$cells stain for $\mathrm{K} 14$ (nascent HBCs, black arrows). Mature, $\mathrm{p} 63^{+} / \mathrm{K} 14^{+} \mathrm{HBC}$, tightly adherent to the basal lamina (mature HBCs, curved arrows), first appear at E17.5 and increase through the first 2 weeks of postnatal life to form a flattened monolayer by P10. B, Quantification of the three stages of HBC development indicates a statistically significant difference as a function of time and cell type (two-way ANOVA). Asterisks indicate a statistically significant difference $\left({ }^{*} p<0.05,{ }^{* *} p<0.01\right)$ by comparison with the previous time point for the cell type indicated. $C$, Illustration of immunostaining for p63 and K14 in the whole $0 \mathrm{E}$ at E14, E16.5, P0, and P3. The pattern described in $\boldsymbol{A}$ is conserved throughout the developing $\mathrm{OE}$; however, the dorsal recess lags behind the ventral $\mathrm{OE}$ in terms of $\mathrm{HBC}$ development. [N.B., Examples of K14 staining without apparent association with p63 - signified as black only — correspond to $H B C$ s in which the nucleus is out of the plane of section.] Scale bars: $(\boldsymbol{A}), 50 \mu \mathrm{m}$; inset, $10 \mu \mathrm{m} ;(\boldsymbol{C}), 100 \mu \mathrm{m}$.

\section{p63 expression anticipates differentiation of HBCs during embryonic development}

Given that HBCs do not appear until the perinatal period when all other cell types of the OE have already emerged, we assayed for the expression of p63 in the embryonic and early postnatal epithelium (Fig. $2 A, B$ ). At embryonic day 12 (E12), no p63 labeling is observed in OE. At E14, $\mathrm{p}^{+}{ }^{+}$cells are concentrated in the apical reaches of the epithelium; none of them contact the basal lamina. At this stage, K14- or K5-labeled cells (Fig. 2A; data not shown) have yet to appear in the OE. For purposes of classification we designated $\mathrm{p} 63^{+} / \mathrm{K} 14^{-}$cells as "HBC progenitors" (Fig. 2B). At E16.5, the density of HBC progenitors is slightly increased compared with E14. In addition, some $\mathrm{p} 3^{+}$cells are weakly labeled by anti-K14 and K5 (data not shown). The nuclei of the $\mathrm{p} 63^{+} / \mathrm{K}_{14}{ }^{+}$cells are elongated and parallel the apicobasal axis. Some of these cells abut the basal lamina, but they are not flattened, and lack the high level of K14 expression that is characteristic of mature HBCs. We classified these cells "nascent HBCs" (Fig. 2 B). At E17.5, the density of HBC progenitors and nascent $\mathrm{HBCs}$ remains constant relative to E16.5. At E17.5 we observe a few "mature HBCs" (defined as flattened cells with abundant $\mathrm{K} 14$, adjacent to the basal lamina). At P0 the density of HBC progenitors decreases sharply, while the populations of nascent HBCs and mature HBCs expand. At P3, the number of mature HBCs continues to increase until $\mathrm{P} 10$. By P10 the OE approaches the adult state and contains a monolayer of flattened, $\mathrm{K}_{14}{ }^{+} \mathrm{HBCs}$ at the basal lamina with few, if any, HBC progenitors and rare nascent HBCs. The time course described above suggests that p63 marks progenitor cells (as indicated in Fig. $2 B$ ) that will come to express K14 and acquire mature HBC morphology. The appearance in the middle of the apicobasal axis followed by their accumulation at the basal lamina suggests that the $\mathrm{p}^{+} 3^{+}$cells are in transit toward the epithelial base. As the cells that initiate p63 expression are neither at the apex of the developing epithelium, where the dividing OPPs are found, nor yet at the base, where the GBCs reside, we call them $\mathrm{OPP} / \mathrm{GBC}$ for convenience.

A mapping of $\mathrm{p} 63$ and K14 expression as they accumulate across the whole $\mathrm{OE}$ demonstrates that the aforementioned pattern is representative of $\mathrm{HBC}$ development overall (Fig. 2C). Interestingly, the ventral $\mathrm{OE}$ displays higher numbers of p63- and K14-expressing cells at earlier time points than the dorsal OE. This is consistent with earlier reports which show that HBC development is delayed in the dorsal versus ventral OE in rats, as well as other accounts of OE embryogenesis (Suzuki and Takeda, 1991; Holbrook et al., 1995).

In sum, the expression of p63 anticipates both molecular (e.g., K5/14 expression) and morphological differentiation of HBCs. The sequence of expression (combined with the role of p63 in maintaining basal cell populations in other epithelia) implicates p63 as a linchpin in the differentiation of this important population of reserve stem cells in the OE. 

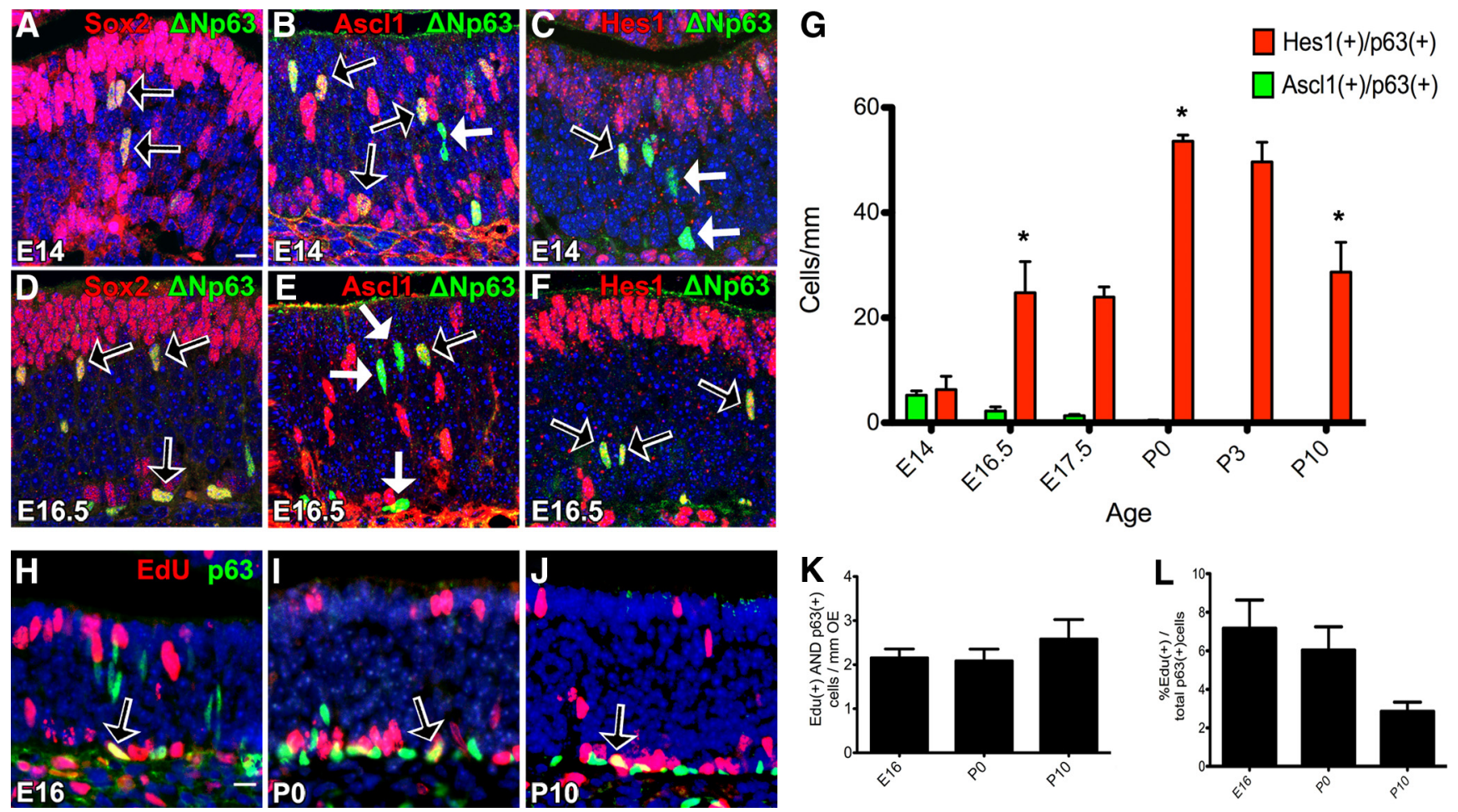

Figure 3. $\mathrm{p} 63{ }^{+} \mathrm{HBC}$ precursors are slow-cycling and express markers of OPPs and GBCS. $\boldsymbol{A}-\boldsymbol{F}$, Embryos were analyzed at $\mathrm{E} 14(\boldsymbol{A}-\boldsymbol{C})$ and $\mathrm{E} 16.5(\boldsymbol{D}-\boldsymbol{F})$ for coexpression of p63 with the $0 \mathrm{PP}$ and $\mathrm{GBC}$ transcription factors Sox2 $(\boldsymbol{A}, \boldsymbol{D})$, Ascl1 $(\boldsymbol{B}, \boldsymbol{E})$, and Hes1 $(\boldsymbol{C}, \boldsymbol{F})$. Black arrows indicate coexpression, while white arrows indicate exclusive expression of p63. $\boldsymbol{G}$, Quantification of p63 ${ }^{+}$cells that are also Hes $1^{+}$or Ascl1 ${ }^{+}$. For Hes1, asterisks indicates $p<0.01$ compared with previous time point by ANOVA analysis. For Ascl1, one-way ANOVA analysis indicates a statistically significant trend over time. $\boldsymbol{H}-\boldsymbol{J}$, Acute pulse EdU incorporation was compared with p63 expression at E16 $(\boldsymbol{H}), \mathrm{PO}(\boldsymbol{I})$, and P10 $(\boldsymbol{J}) . \boldsymbol{K}, \boldsymbol{L}$, Analysis of the number of EdU ${ }^{+}$and p63 ${ }^{+}$cells $/ \mathrm{mm}$ of $0 \mathrm{E}(\boldsymbol{K})$ and the percentage of p $63^{+}$that incorporate EdU $(\boldsymbol{L})$ reveal no significant differences during development by ANOVA analysis. Scale bars, $10 \mu \mathrm{m}$.

p63 is expressed along with various molecular markers of GBCs and OPPs

We sought to classify the $\mathrm{p} 63^{+}$cells of the embryonic OE by comparing p63 expression with other transcription factors characteristic of the progenitor cell types of the OE. We first examined Sox2, a marker common to OPPs and adult basal cells; all of the p $63^{+}$progenitors also label for Sox 2 protein (Fig. $3 A, D$ ). Other markers that colabel with p63 are characteristic of what are believed to be more committed subsets of progenitor cells. For example, a low percentage of $\mathrm{p}^{+} 3^{+}$cells express Ascl1, a bHLH transcription factor usually thought to convey a commitment to neuronal differentiation (Cau et al., 2002). The $\mathrm{p}^{+} 3^{+} / \mathrm{Ascl}^{+}$ cells are most prominent at E14, becoming scant at E16.5 (Fig. $3 B, E)$. In contrast, $\mathrm{p}^{+}{ }^{+}$cells that colabel with anti-Hes 1 antibodies increase during the same time period (Fig. 3C,F). Hes 1 is a bHLH transcription factor that is thought to oppose the action of Ascll and is characteristic of Sus cells or GBCs differentiating into Sus cells in the normal and regenerating epithelium, respectively. The $\mathrm{p} 63^{+} / \mathrm{Hes} 1^{+}$cells are a different population from the p $63^{+} / \mathrm{Ascl}^{+}$cells_-double-labeling with Ascl1 and Hes1 antibodies stains nonoverlapping sets of cells at all stages (data not shown). Nascent and mature HBCs continue to express Hes1 during early postnatal development. While many $\mathrm{p} 63^{+}$cells still stain for Hes 1 at P10, the intensity of this staining is reduced by comparison with earlier time points and is completely absent by the time the animal reaches adulthood (Manglapus et al., 2004). The coexpression of incipient p63 and heretofore lineage-restricted transcription factors is unexpected and lays the foundation for potential dynamic interactions within the transcriptional network during lineage commitment. p63 marks slowly dividing progenitor cells

HBCs in the adult OE are slow-cycling cells with $\sim 2$ dividing $\mathrm{HBCs} / \mathrm{mm} \mathrm{OE}$ dividing under homeostatic conditions (Leung et al., 2007). We labeled proliferating cells acutely with the thymidine analog EdU at E16, P0, and P10 (Fig. 3H-J). Throughout the perinatal time course of HBC development, there is no significant difference in the number of $\mathrm{p}^{+} 3^{+} / \mathrm{EdU}^{+}$ cells $/ \mathrm{mm}$ OE $(\sim 2$ cells $/ \mathrm{mm} \mathrm{OE})$ (Fig. $3 K)$. Since there are fewer $\mathrm{p} 63^{+}$cells early in development, we also analyzed the percentage of the total number of $\mathrm{p} 3^{+}$cells that are $\mathrm{EdU}{ }^{+}$. The percentage of EdU ${ }^{+} / \mathrm{p} 63^{+}$cells trends downward during development, approaching statistical significance $(p=0.06$, one-way ANOVA, Kruskal-Wallis statistic $=5.600)($ Fig. $3 L)$. The apparent trend may be due to a higher number of cells with newly acquired expression of p63. Such cells may have incorporated EdU before they expressed p63. These data suggest that $\mathrm{p} 63{ }^{+} \mathrm{HBC}$ progenitor cells become slow-cycling before their full differentiation into mature HBCs.

\section{Ascl1 knock-out causes a delay in the OE in p63 expression and $\mathrm{HBC}$ differentiation}

To test the hypothesis that $\mathrm{p} 63^{+} \mathrm{HBC}$ progenitors might pass through a phase of Ascll expression, we analyzed the embryonic development of $A s c l 1^{-1-}$ OE using a $\triangle M a s h 1$-GFP knock-in line (Wildner et al., 2006). We have recently observed a lag in HBC differentiation in the OE of Ascl1 knock-out (KO) embryos, but no delay in Ascl1 heterozygous (Het) compared with wild-type (WT) mice (R. C. Krolewski, A. Packard, W. Jang, and J. E. Schwob, unpublished observation). Here we show that p63 expression in the $\mathrm{KO}$ also lags by comparison with the Ascl1 WT or 

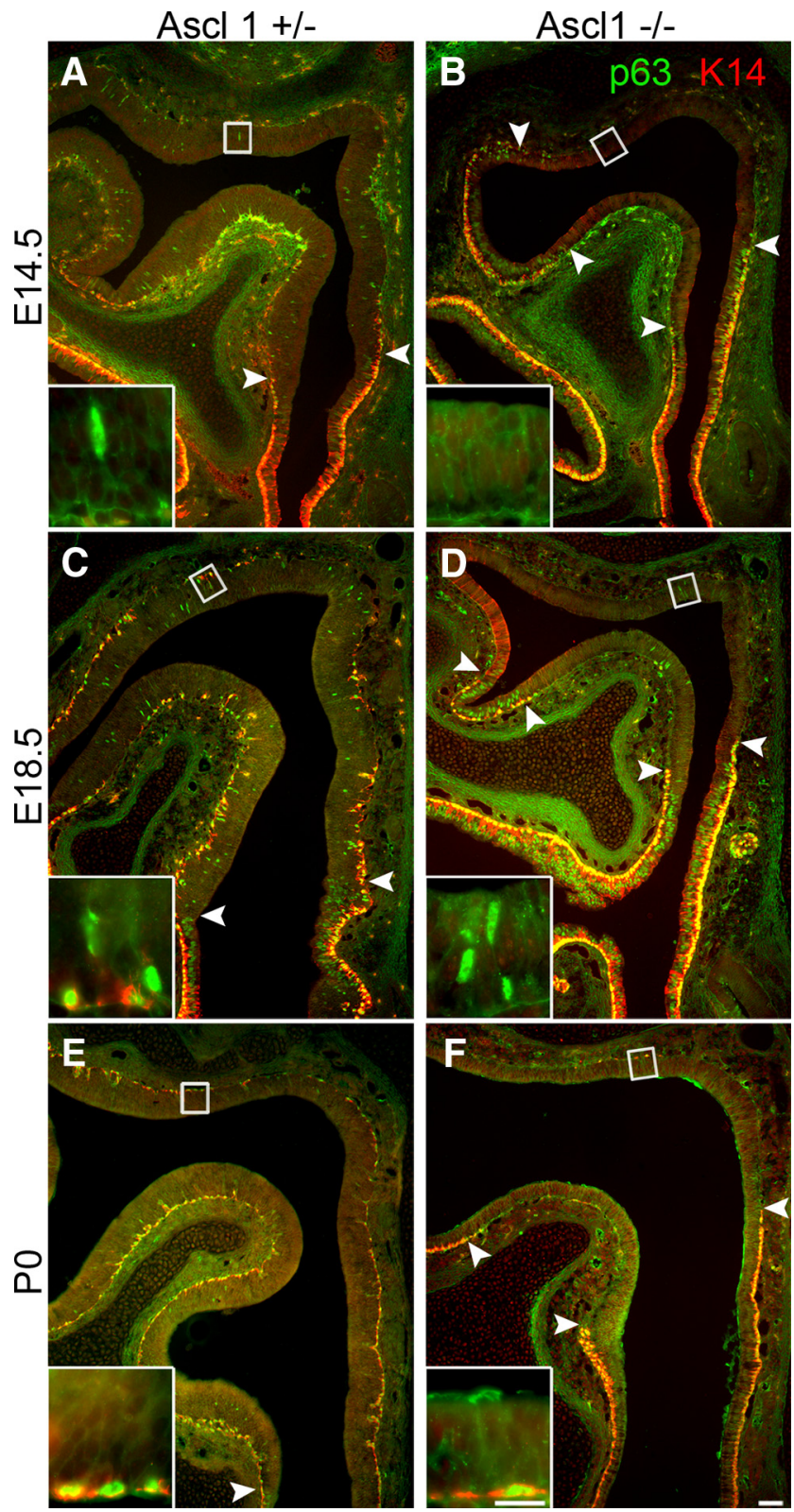

Figure 4. p63 expression and HBC differentiation are delayed in Ascl1 KO OE. Arrowheads represent the borders between $\mathrm{OE}$ and respiratory epithelium, where $\mathrm{p} 63$ expression is unchanged from normal. $\boldsymbol{A}, \boldsymbol{B}, \mathrm{AtE} 14.5, \mathrm{p} 63^{+} / \mathrm{K} 14^{-} \mathrm{HBC}$ progenitors are present in Ascl1 Het $(\boldsymbol{A})$, but not KO (B) OE. C, D, At E18.5, many p $63^{+} / \mathrm{K} 14^{+}$nascent and mature HBCs are present in the Het $(C)$, but not $K 00 \mathrm{E}$, where some $\mathrm{p} 63^{+} / \mathrm{K} 14^{-} \mathrm{HBC}$ progenitors are just beginning to appear $(\boldsymbol{D})$. $\boldsymbol{E}, \boldsymbol{F}, \mathrm{At} P 0$, many mature HBCs are present in the Het $(\boldsymbol{E})$, but not $\mathrm{KO} O \mathrm{E}(\boldsymbol{F})$. Scale bars: $25 \mu \mathrm{m}$; insets, $10 \mu \mathrm{m}$.

Het epithelium (Fig. 4). At E14.5, $\mathrm{p}^{+}{ }^{+}$cells cannot be detected in the Ascll knock-out OE in contrast to the sizeable population of p63 ${ }^{+}$cells in the Ascl1 Het littermates (Fig. 4A,B). At E18.5, the KO OE still contains very few $\mathrm{p} 63^{+}$cells, while the Het OE has robust p63 and K14 expression, which parallels the developmental increase seen in the C57BL/6 strain described earlier (Fig. $4 C, D)$. At $\mathrm{P} 0$, there are only a few $\mathrm{p} 63^{+} / \mathrm{K} 14^{+}$cells in the $\mathrm{KO}$, as opposed to the large population of fully differentiated and differentiating HBCs in the Het OE (Fig. $4 E, F$ ). Thus, while HBCs do eventually form in Ascl1 $\mathrm{KO}$ animals, there is a substantial delay in their appearance, suggesting an alternate, Ascl1-independent, pathway to HBC development.
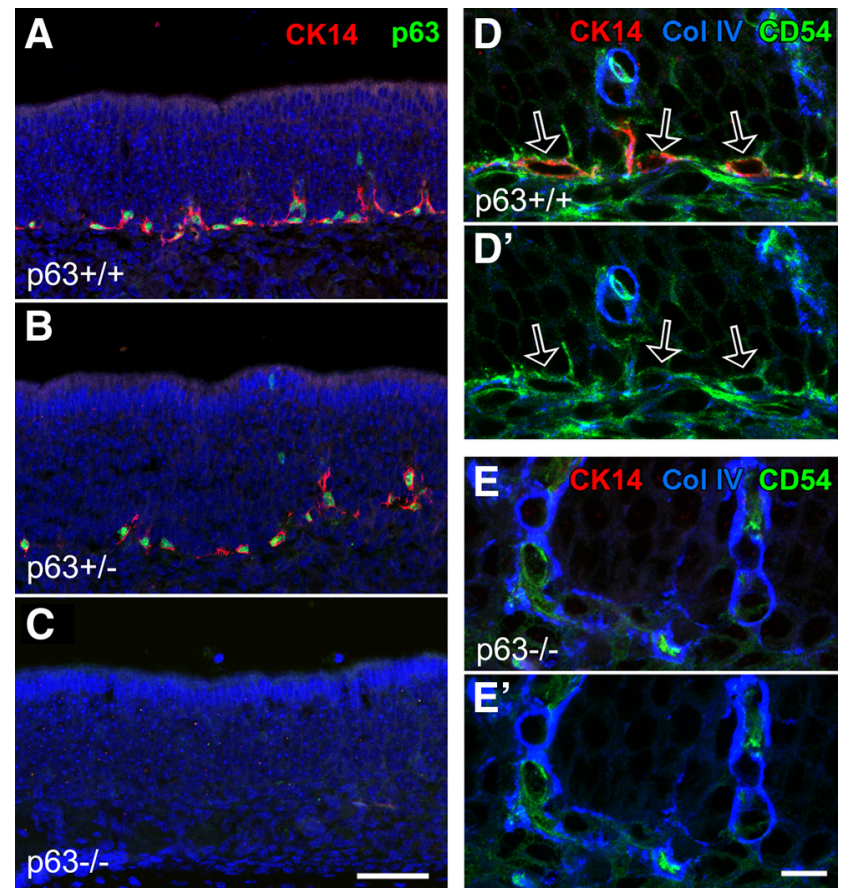

Figure 5. $\mathrm{p} 63 \mathrm{KO}$ prevents the development of $\mathrm{HBCS}$ at $\mathrm{PO} . \boldsymbol{A}$, p63 wild-type $\mathrm{OE}$ displays

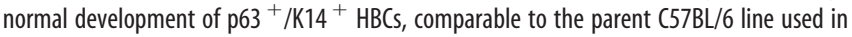
Figure 1. B, p63 heterozygous 0 E displays reduction in $\mathrm{p} 63^{+}$cells and a delay in $\mathrm{HBC}$ formation. C, p63 knock-out 0 E contains no p $63^{+} / K 14^{+}$HBCS. D, $D^{\prime}$, In WT OE, CD54, another marker of $\mathrm{HBC}$, is expressed by $\mathrm{K} 14^{+}$cells, i.e., cells above the basal lamina (marked by type IV collagen). $\boldsymbol{E}, \boldsymbol{E}^{\prime}$, No $\mathrm{CD} 54$ staining is observed in the knock-out 0E above the basal lamina. Cells within the lamina propria accompanying capillary loops as they traverse the epithelium (asterisks) are $\mathrm{CD}^{+} 4^{+}$. Scale bars: $(\boldsymbol{A}-\boldsymbol{C}), 50 \mu \mathrm{m} ;(\boldsymbol{D}, \mathbf{E}), 10 \mu \mathrm{m}$
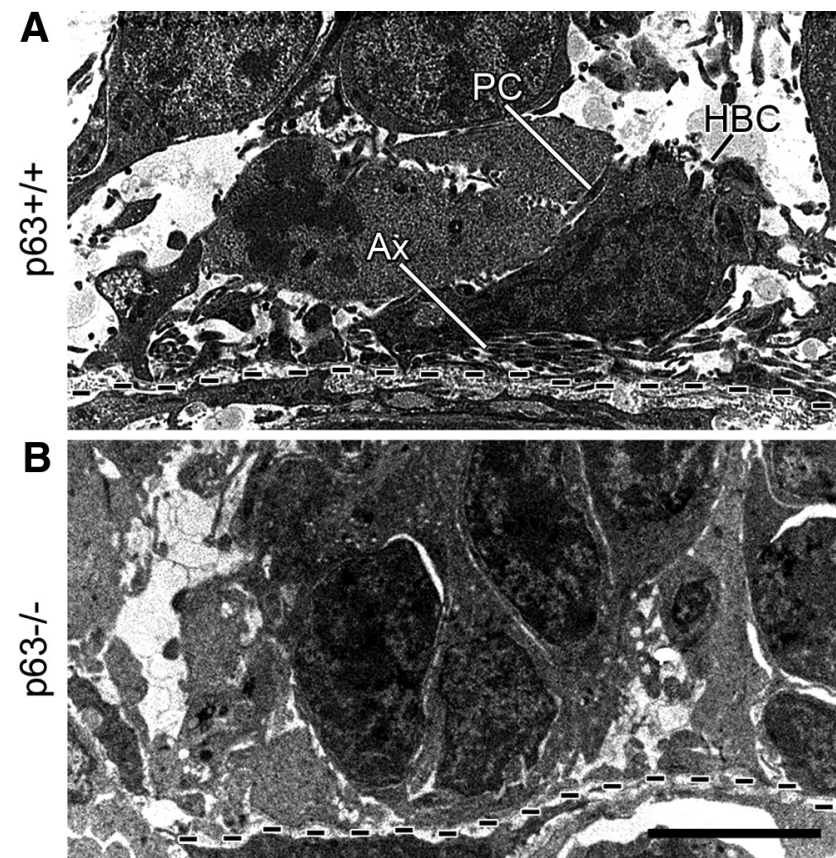

Figure 6. Electron microscopy confirms the absence of morphologically distinct HBCs in p63 KO OE. A, WT OE contains cells with flattened HBC morphology and focal attachments to the basal lamina (dotted line). These cells arch over bundles of olfactory axons (Ax). A primary cilium $(\mathrm{PC})$ is visible on a dividing $\mathrm{GBC} . \boldsymbol{B}$, In $\mathrm{p} 63 \mathrm{KO} 0 \mathrm{E}, \mathrm{no} \mathrm{HBC}$ are evident, in contrast to WT $(\boldsymbol{A})$. Instead, $G B C$ s are directly apposed to, but do not form focal attachments onto, the basal lamina. GBCs do not arch over axon bundles. Dashed line, Basal lamina. Scale bar, $5 \mu \mathrm{m}$. 
$\mathrm{p} 63^{+/+}$
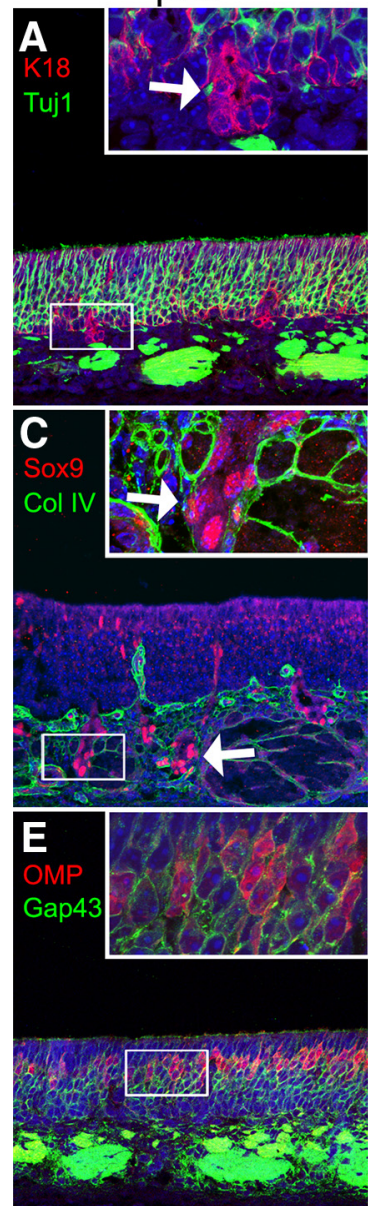

$\mathrm{p} 63^{-1-}$
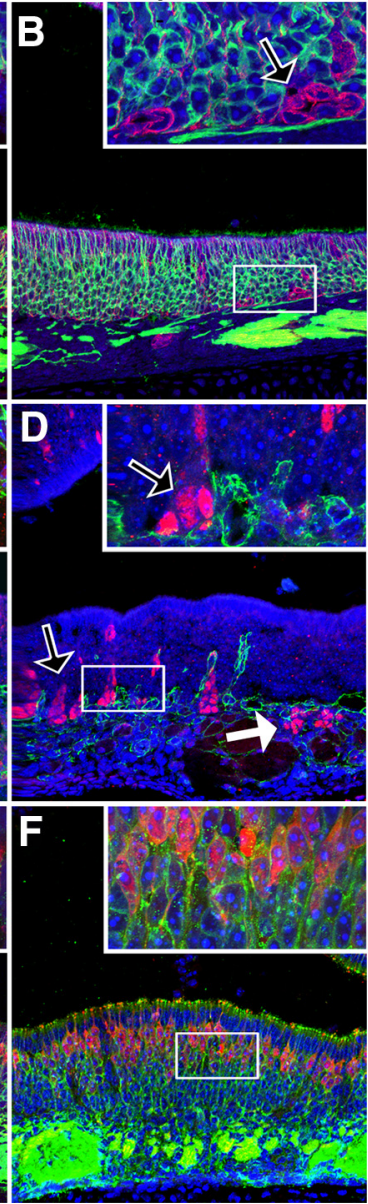
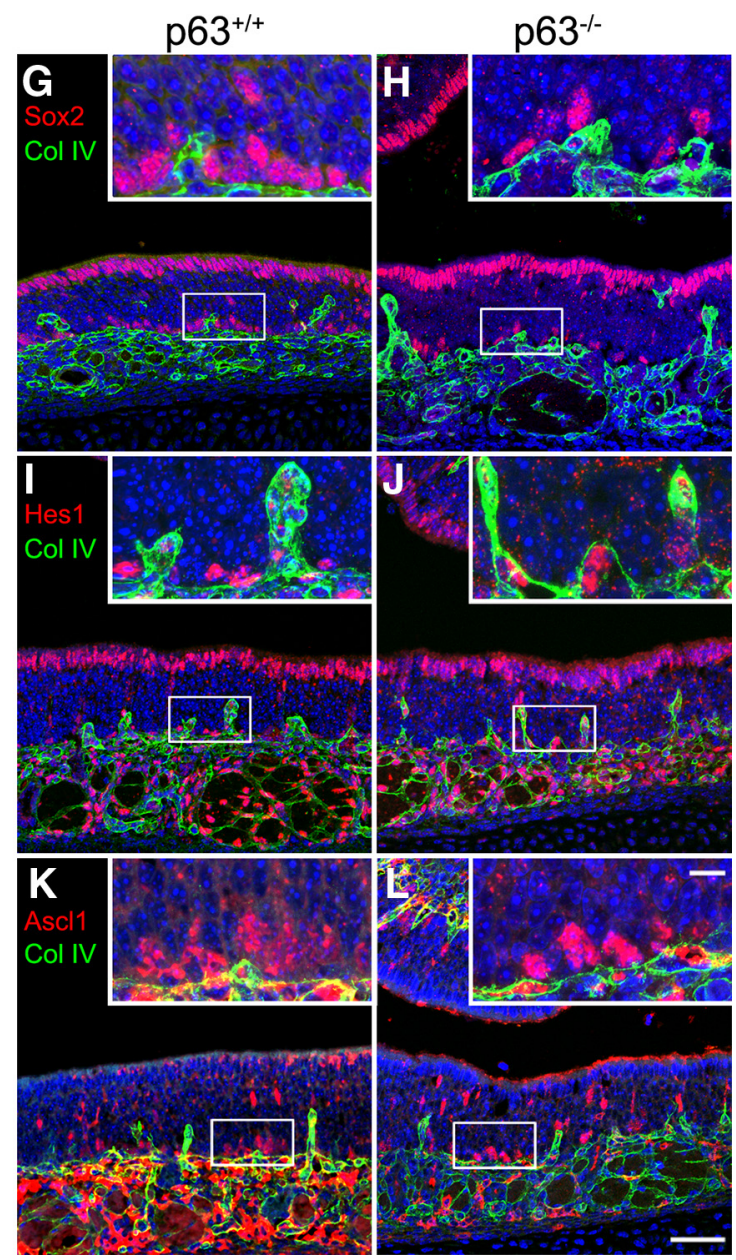

Figure 7. With the exception of the HBCs, the cell types and epithelial architecture emerge normally in the p63 KO OE. A, B, Both WT and K0 OE contain Tuj ${ }^{+}$neurons and K18 ${ }^{+}$Sus cells. K18 also marks Bowman's ducts/glands. In the WT these cells extend into the lamina propria as mature glands (white arrows). In the $\mathrm{KO}, \mathrm{K}_{18}{ }^{+}$cells are frequently bunched above the basal lamina (black arrows). C, D, Sox9, another marker of duct/gland cells, is expressed in normal glands in the lamina propria of the WT mucosa. In the K0, piles of Sox9 ${ }^{+}$cells accumulate above the basal lamina in the epithelium proper. $E, F$, Neurons in WT and KO OE are approximately equivalent in the proportion of immature OSNs (GAP43 ${ }^{+}$and basally situated) versus mature 0 SNs (OMP ${ }^{+}$and apically placed). $\boldsymbol{G}, \boldsymbol{H}$, Sox2 is expressed in Sus cells of WT and KO OE. In the basal cell compartment, fewer Sox $2^{+}$cells can be seen in the K0 than in the WT. $\boldsymbol{I}, \boldsymbol{J}$, , Fewer Hes $1^{+}$cells are present in the basal OE of p63 KO OE. $K, L$, Ascl1 $^{+}$cells are equally abundant in WT and KO OE. Type IV collagen marks the basal lamina in $\mathbf{C}, \boldsymbol{D}$, and $\mathbf{G}-\boldsymbol{L}$. Scale bars: $50 \mu \mathrm{m}$; insets, $10 \mu \mathrm{m}$.

p63 is required for timely morphological and molecular differentiation of $\mathrm{HBCs}$

To test whether p63 is an essential factor regulating HBC differentiation, we next analyzed p63 KO mice in which the $p 63$ gene was disrupted via retroviral insertion into the coding sequence of the gene (Mills et al., 1999). Because the KO mice die soon after birth due to severely compromised skin development, we analyzed KO, Het, and WT animals as they were born. At this time point, $\mathrm{K} 14$ expression in the $\mathrm{OE}$ of $p 63 \mathrm{KO}$ mice is not readily detectable. $\mathrm{p} 63^{+} \mathrm{HBCs}$ are evident in the OE of the $p 63 \mathrm{Het}$ littermates, but are reduced in number to $41 \%( \pm 9 \%)$ of WT, suggesting that $\mathrm{HBC}$ development is delayed due to haploinsufficiency (Fig. $5 A-C$ ). The OE of $p 63 \mathrm{KO}$ mice also lacks detectable levels of another early HBC marker, CD54 (ICAM-1). The absence of $\mathrm{p} 63$ in the $\mathrm{KO}$ animals does not prevent expression of K14 and CD54 in other cell types: CD54-labeled cells are evident within the lamina propria and basal lamina-delimited capillary loops that extend into the OE (Fig. 5D,E). K14 is expressed by patches of cells within the tongue epithelium of the knock-out mice (data not shown). Together, the data suggest that timely morphological and molecular HBC differentiation is absent in the $\mathrm{OE}$ of the p63-null mice.
To confirm that the lack of marker expression indicates an absence of morphologically distinct HBCs, we assessed the basal population of the $p 63 \mathrm{WT}$ versus KO OE by transmission electron microscopy. WT OEs contains flat cells with scant cytoplasm and foot processes that contact the basal lamina, consistent with prior ultrastructural analysis of HBCs (Graziadei and Graziadei, 1979; Holbrook et al., 1995). In keeping with past reports (Graziadei and Graziadei, 1979; Holbrook et al., 1995), these HBCs arch over bundles of axons (Fig. 6A). Cells with these morphological characteristics are not found in the p63 KO. Instead, we see round cells, some of which touch the basal lamina but do not form foot processes. Furthermore, axon bundles in the OE of $p 63 \mathrm{KO}$ mice are not covered over by the arching processes of basal cells as they are in the WT (Fig. 6B). Together, the above data demonstrate that p63 is necessary for differentiation of HBCs from a placodally derived progenitor population.

Strikingly, the other cellular constituents of the OE are grossly normal in the $\mathrm{p} 63 \mathrm{KO}$, including neurons (expressing neuronspecific tubulin and labeled with Tuj1), cells of Bowman's glands and ducts (expressing Sox9 and K18), and Sus cells (expressing Sox 2 and K18) (Fig. $7 A-D$ ). The neuronal population in the $\mathrm{KO} \mathrm{OE}$ can be subdivided into mature, $\mathrm{OMP}^{+}$(olfactory 

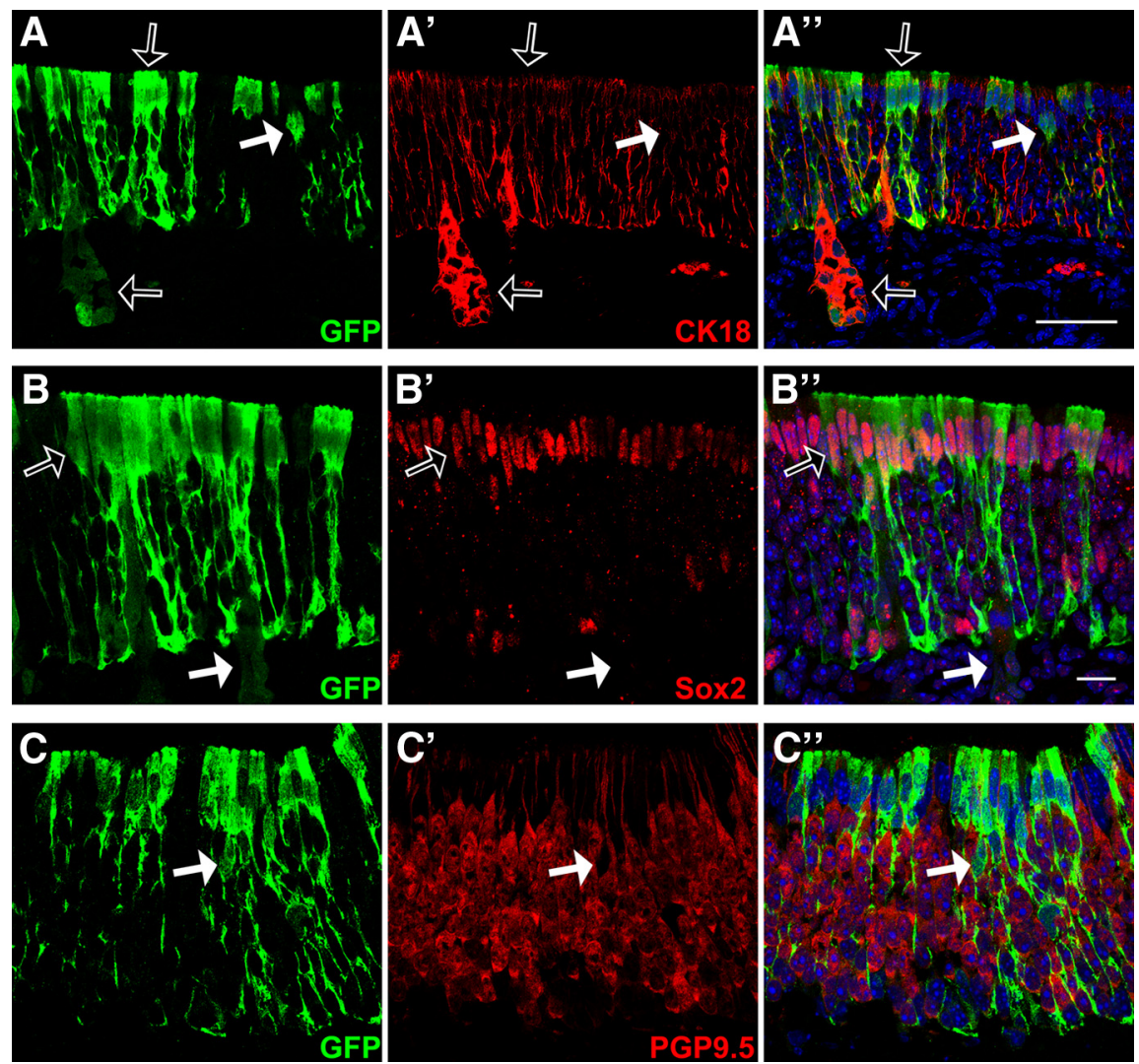

Figure 8. $\mathrm{OPP} / \mathrm{GBC}$ differentiate into non-neuronal subtypes in the absence of $\mathrm{p} 63$. $\boldsymbol{A}$, The $0 \mathrm{E}$ of the $\Delta \mathrm{Np} 63-\mathrm{GFP}{ }^{-1-}$ contain $\mathrm{GFP}^{+} / \mathrm{CK}_{18}{ }^{+}$cells that resemble Sus, duct, and Bowman's gland cells (black arrows). However, some of the GFP ${ }^{+}$cells lack CK18 and are situated basal to the layer of Sus cells, and most likely correspond to OPP/GBCs that have more recently attempted to express the null $\Delta$ Np63GFP locus and have not yet had the time to differentiate further to Sus or duct/gland cells (white arrows). $B, \mathrm{GFP}^{+}$cells with Sus morphology are Sox $2^{+}$, while GFP ${ }^{+}$cells with the flattened shape of duct cells or the acinar arrangement of gland cells are Sox $2^{-}$, just like the mature cell types. C, GFP ${ }^{+}$cells are PGP9.5 ${ }^{-}$, suggesting that the GFP-marked OPPs are committed to a non-neuronal lineage. Another example of a GFP ${ }^{+} \mathrm{OPP} / \mathrm{GBC}$ is indicated (white arrow). Black arrows, Colocalization; white arrows, no colocalization. Scale bars: $(\boldsymbol{A}), 50 \mu \mathrm{m} ;(\boldsymbol{B}, \boldsymbol{C}), 20 \mu \mathrm{m}$.

marker protein-positive) and immature, GAP43 ${ }^{+}$, groups in approximately the same number and proportion as WT OE, indicating that neurogenesis is not disrupted by p63 knock-out (Fig. $7 E, F)$. Moreover, $\mathrm{OMP}^{+}$olfactory axons fill the glomeruli of the olfactory bulb in the $\mathrm{KO}$ mice, suggesting that the bulb is also innervated more or less appropriately in the absence of p63 (data not shown). We did observe a subtle abnormality in the development of Bowman's glands and ducts. Whereas the glands/ ducts project well into the lamina propria of the WT OE at birth (Fig. $7 A, C$, white arrows), their extension below the basal lamina is stunted in the $\mathrm{KO}$ mucosa. In the $\mathrm{KO}$ mice, some glands push into the lamina propria, but Sox ${ }^{+} / \mathrm{K}_{1} 8^{+}$cells with gland morphology are often clustered in the OE superficial to the basal lamina (marked by type IV collagen) (Fig. $7 B, D$, black arrows). Clusters like this are rarely if ever seen in the WT OE. Since p63 can regulate production of components of the basal lamina in the epidermis, it is possible that the absence of HBCs may cause defects in the olfactory basal lamina that may inhibit proper extension of gland cells into the lamina propria during development (Koster et al., 2007).

We also assayed for the presence of progenitor cell populations in the knock-out OE using the markers described earlier. Sox 2 protein is expressed in the Sus and basal cells of p63 KO OE; however, the number of Sox $2^{+}$cells is diminished in the $\mathrm{KO}$ compared with WT. Since HBCs are Sox $2^{+}$, this decrease may be due to the absence of $\mathrm{HBCs}$ in the $\mathrm{KO}$ described above (Fig. 7G,H). Similarly, fewer basal cells in the p63 KO OE express Hes1, which is still expressed in developing HBCs at this stage (Fig. 7 I, J). Expression of Ascl1 and of NeuroD1, markers of early and late neural precursor cells, respectively, does not significantly differ between knock-out and wild-type animals (Fig. $7 \mathrm{~K}, L$; data not shown). In addition, we examined the expression of CD190, Thyl, and vimentin to assess the status of the fibroblastic cells of the lamina propria and of brain lipid-binding protein for the olfactory ensheathing cells, respectively. Our examination of the former set of markers was motivated by recent demonstrations that a stem-like cell is present within the mesenchymal elements deep to the OE. However, no difference was observed between the $\mathrm{KO}$ and wild type with regard to the distribution of these cell types, nor the rate of their proliferation (data not shown).

\section{p63 is required specifically for $\mathrm{HBC}$ differentiation and not for release of OPP/GBCs from an immature phenotype}

There are two likely interpretations of the data thus far: (1) p63 is required to actively drive the differentiation of $\mathrm{HBCs}$ from a subset of OPP/GBCs induced to express p63 by unknown mechanism(s); and (2) p63 is required to release a subclass of OPP/GBCs from an immature state, and allow them to differentiate. In the first case, OPP/GBCs induced to express p63 in the knock-out would simply adopt an alternate cell fate. In the second case any OPPs that might be induced to express $\mathrm{p} 63$ would not differentiate and would instead remain immature. To distinguish between these possibilities, we analyzed a $\Delta$ Np63 knock-in mouse model in which the $\Delta$ Np63-specific exon has been replaced by the green fluorescent protein ( $\Delta$ Np63GFP). Homozygous mice are thus null for the $\Delta \mathrm{Np} 63$ gene product, but retain expression of TAp63 (Romano, Smalley, and Sinha, unpublished observation). In the $\mathrm{OE}$, skin, and limbs, among other tissues,

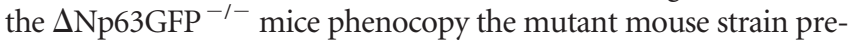
sented above, in which both forms are eliminated, once again validating the criticality of the $\Delta$ Np63 isoform versus TAp63 in the OE.

To determine the cell fate of OPP/GBCs that are pushed to express $\Delta \mathrm{Np} 63$, but cannot do so as a result of gene deletion, we

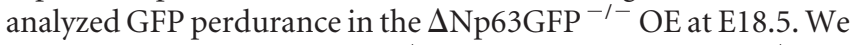
find that the majority of $\mathrm{GFP}^{+}$cells at this age are $\mathrm{CK}_{18}{ }^{+}$and have the morphology of either Sus or Bowman's gland cells (Fig. $\left.8 A-A^{\prime \prime}\right)$. The GFP ${ }^{+}$Sus cells are Sox $2^{+}$, while the $\mathrm{GFP}^{+}$gland cells are Sox $2^{-}$, which are their marker profiles in the normal OE (Fig. $8 B-B^{\prime \prime}$ ). Interestingly, none of the $\mathrm{GFP}^{+}$cells stained for PGP9.5 or Tuj1, suggesting that these OPP/GBCs are committed to a non-neuronal lineage, which is in line with the expression of Hes 1 by HBC progenitors (Fig. $8 C-C^{\prime \prime}$ ). Some GFP ${ }^{+}$cells did not resemble Sus or gland cells and did not express the neuronal markers PGP9.5 or Tuj1, suggesting that a subset of OPP/GBCs is 

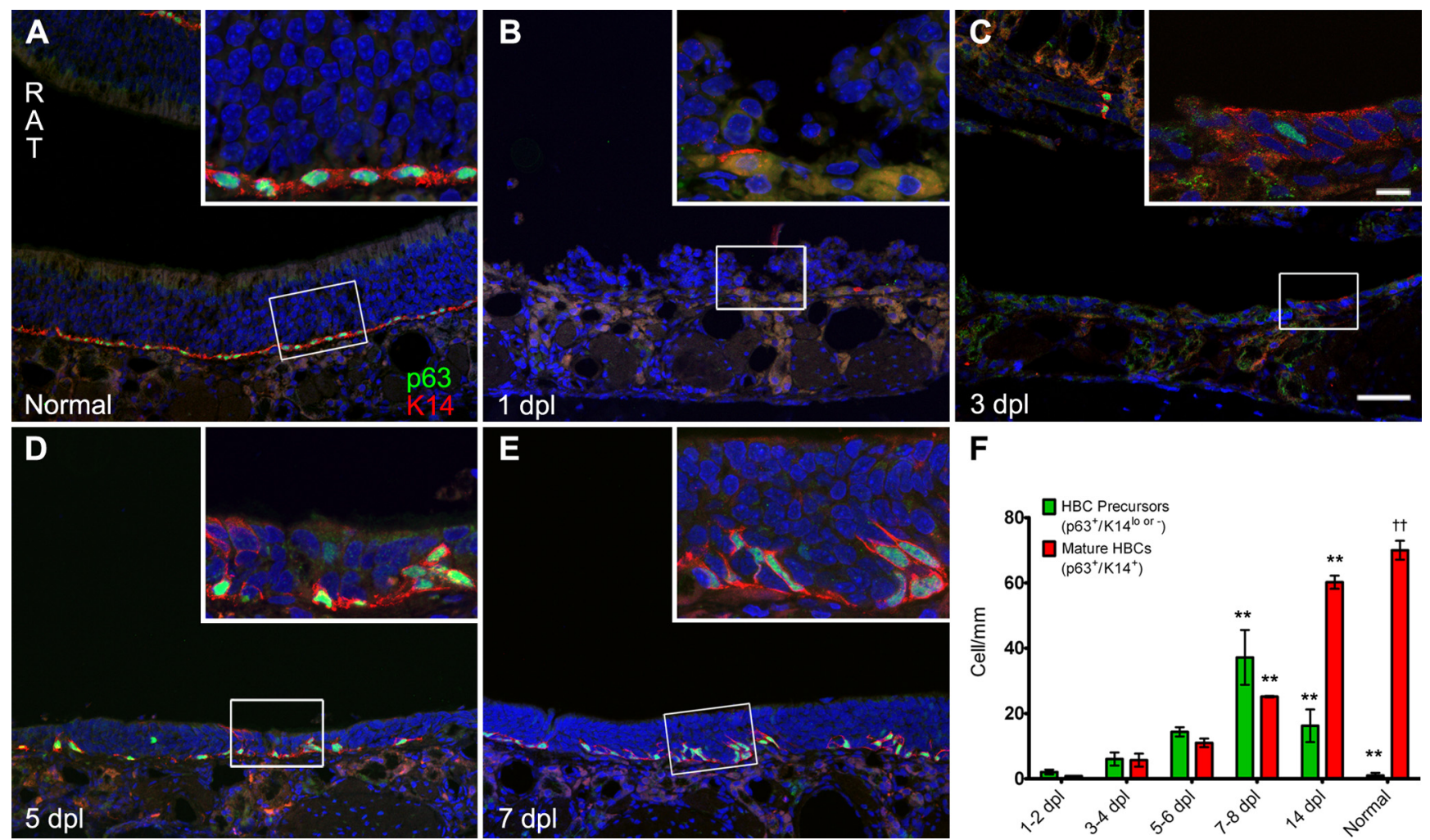

Figure 9. p63 expression anticipates HBC differentiation in the regenerating ventral rat $0 \mathrm{E} . A$, Normal rat $0 \mathrm{E}$ contains p $63^{+} / \mathrm{K} 14^{+} \mathrm{HBCs}$ (Fig. 1 A). $B$, At $1 \mathrm{~d}$ post-MeBr lesion (dpl), few ifany p63 ${ }^{+}$or K14 ${ }^{+}$ cells remain evident in the ventral part of the $0 \mathrm{E}$. $C$, As early as $3 \mathrm{dpl}, \mathrm{p} 63^{+}$cells can be observed at a remove from the basal lamina. $\boldsymbol{D}, \mathrm{At} 5 \mathrm{dpl}$, the population of $\mathrm{HBC}$ precursors expands. These precursors are rarely void of 14 protein, but frequently express $\mathrm{K} 14$ at a lower level than mature $\mathrm{HBCS}$. $\mathrm{E}, \mathrm{At} 7 \mathrm{dpl}, \mathrm{HBC}$ precursors are still settling down on the basal lamina. $F$, Counts of differentiating $\mathrm{HBC}$ s during regeneration of the ventral rat 0 E are significantly different as a function of time and cell type (two-way ANOVA). Asterisks indicate a statistically significant difference ${ }^{* *} p<0.01$ ) by comparison with the previous time point for the cell type indicated. Daggers indicate that normal 0 E is significantly different from 1 to $2 \mathrm{dpl} 0 \mathrm{E}\left({ }^{\mathrm{tt}} p<0.01\right)$. Scale bars, $50 \mu \mathrm{m}$; insets, $10 \mu \mathrm{m}$.

still driven to express the $\Delta \mathrm{Np} 63$ locus at this age (Fig. $8 A, C$; data not shown). Together, our data strongly suggest that p63 functions actively to drive $\mathrm{HBC}$ differentiation of a progenitor committed to making non-neuronal cells, rather than passively to release OPP/GBCs from an uncommitted, immature state.

\section{Recovery of ventral rat $\mathrm{OE}$ recapitulates the developmental sequence of $\mathrm{HBC}$ formation}

The rodent $\mathrm{OE}$ is lesioned by passive inhalation of the olfactotoxic gas $\mathrm{MeBr}$ (Schwob et al., 1995). MeBr destroys the differentiated cells (neurons, Sus cells, microvillar cells) of the OE, but spares a heterogeneous population of basal progenitor cells, truncated ducts, and damaged Bowman's glands. The remaining cells are able to reconstitute the epithelium fully in 2-3 weeks. However, the response of HBCs to the toxin is subtly different in rat versus mouse $\mathrm{OE}$, which provides an analytic advantage. We have previously shown that the ventral domain of the $\mathrm{MeBr}$-lesioned rat $\mathrm{OE}$ becomes almost completely devoid of $\mathrm{K} 5 / 14^{+} \mathrm{HBCs}$ by 1-3 d after exposure (Schwob et al., 1995). The HBCs then reappear progressively between 3 and $14 \mathrm{~d}$ postlesion $(\mathrm{dpl})$. As such, regeneration of the ventral rat $\mathrm{OE}$ after lesion recapitulates development.

As expected, the number of $\mathrm{p} 63^{+} / \mathrm{K} 14^{+}$cells (HBCs) in the ventral OE drops off at 1 and $3 \mathrm{dpl}$ compared with normal OE (Fig. 9A,B). As regeneration proceeds from 3 to $5 \mathrm{dpl}$, p63 ${ }^{+} /$ $\mathrm{K} 14^{-}$cells (HBC progenitors) appear, although they are less numerous than during embryonic development (Fig. 9C,D). Instead, most nascent $\mathrm{p} 63^{+}$cells express low levels of K14, suggesting that these cells are much quicker to express HBC cytokeratins than embryonic HBC progenitors. Because it is difficult to discriminate cells that lack K14 expression from those with very low levels of K14-labeling, we grouped $\mathrm{p} 63^{+}$/ $\mathrm{K}_{14}{ }^{-}$and $\mathrm{p} 63^{+} / \mathrm{K} 14$ (weak) cells into a single category for purposes of the quantitative analysis (Fig. $9 F$ ). These "HBC precursors" increase in number during the first 1.5 weeks of regeneration until a nearly mature $\mathrm{HBC}$ layer is reestablished by 2 weeks postlesion (Fig. $9 E, F$ ). These data further validate a role for p63 in maintaining a reserve stem cell population within the cellular dynamics of the OE.

\section{$\mathrm{p} 63$ is transiently downregulated in the regenerating $\mathrm{OE}$}

In contrast to the ventral $\mathrm{OE}$ of the rat, the mouse $\mathrm{OE}$ retains $\mathrm{K}_{14}{ }^{+}$basal cells after MeBr lesion. However, we find that at $1 \mathrm{dpl}$, many of these $\mathrm{K}_{14}{ }^{+}$cells are more lightly stained for $\mathrm{p} 63 \mathrm{com}-$ pared with normal OE (Fig. 10A,B). Because downregulation of p63 levels appears to be a direct consequence of $\mathrm{MeBr}$ lesion, we categorized the $\mathrm{p} 63^{-} / \mathrm{K}_{14}{ }^{+}$cells in our quantification as "activated HBCs," while the $\mathrm{p} 63^{+} / \mathrm{K} 14^{+}$cells were classified as "quiescent HBCs" (Fig. 10 F). At 2 dpl, K14 ${ }^{+}$cells no longer form a monolayer but have accumulated to several cell layers thick. At this time, some $\mathrm{K} 4^{+}$basal cells have regained expression of $\mathrm{p} 63$, but many more apically situated $\mathrm{K} 4^{+}$cells are p63- (Fig. 10C). At $3 \mathrm{dpl}$, all of the basal-most cells of the regenerating OE strongly express p63, while the more apical p $63^{-} / \mathrm{K} 14^{+}$layer continues to expand (Fig. $10 \mathrm{D}$ ). The population of $\mathrm{p} 63^{-} / \mathrm{K} 14^{+}$cells remains prominent until $5 \mathrm{dpl}$, when their number begins to drop off. This drop-off continues 7-14 dpl until there are few if any $\mathrm{p}^{-} 3^{-} /$ $\mathrm{K}_{14}{ }^{+}$cells present in the tissue (Fig. 10E,F). 

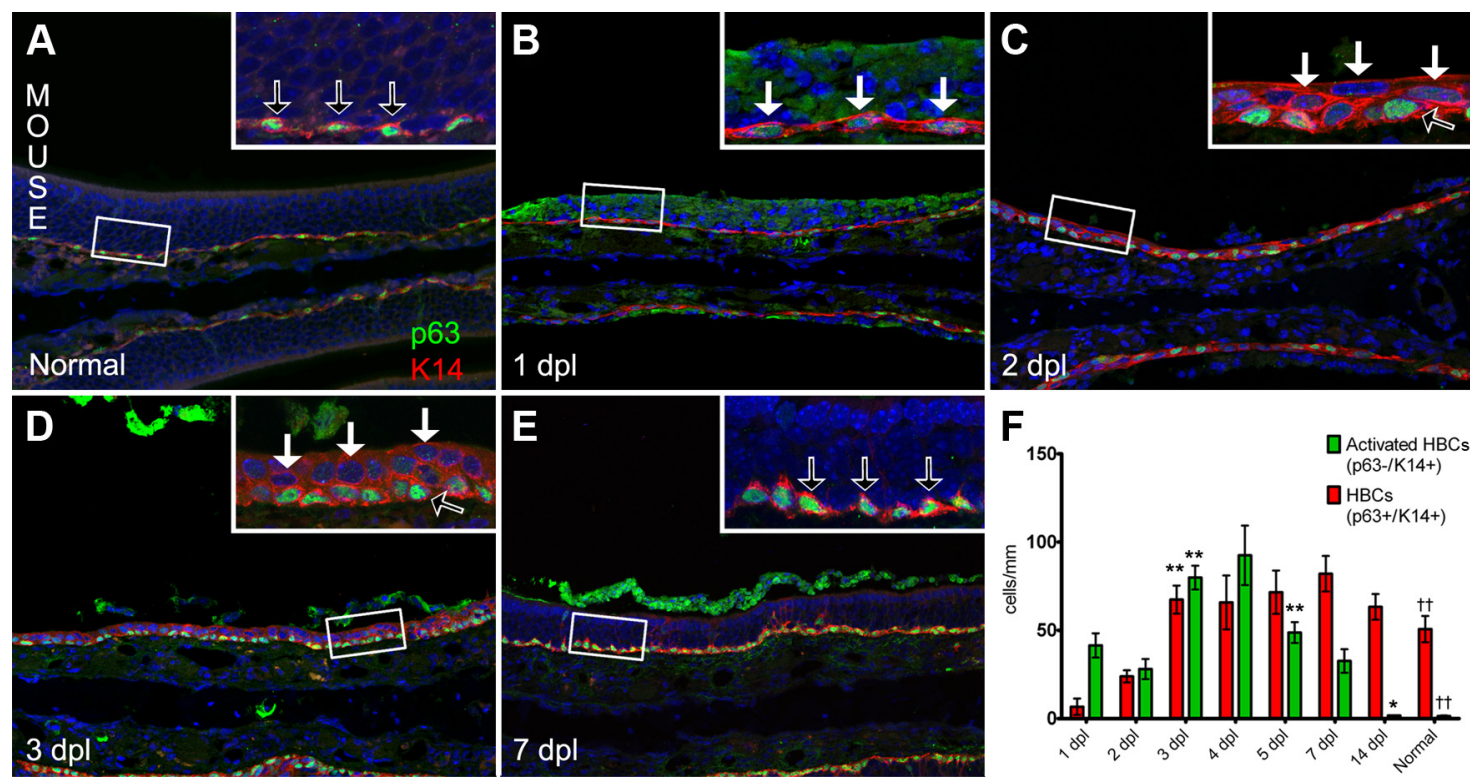

Figure 10. p63 protein levels are transiently downregulated after MeBr lesion in the mouse. $A$, p63 and K14 staining in normal mouse $\mathrm{HBCs}$ (black arrows). B, At $1 \mathrm{dpl}, \mathrm{K} 14^{+}$cells are flat and directly apposed to the basal lamina, but have lower levels of $\mathrm{p} 63$ staining (activated $\mathrm{HBC}$, white arrows). C, At $2 \mathrm{dpl}$, a second layer of $\mathrm{K} 14^{+}$cells is found apical to the usual HBC layer. The apical cells are $63^{-}$(white arrows), while many of the basal-most K14 ${ }^{+}$cells have regained p63 protein expression (black arrows). D, At 3 dpl, the apical layer of K14 ${ }^{+} / \mathrm{p} 63^{-}$cells has expanded, while all of the basal-most $\mathrm{K}_{4}{ }^{+}$cells now express high levels of p 63 protein. $\boldsymbol{E}$, By $7 \mathrm{dpl}$, there are fewer activated $\mathrm{HBC}$. Most of the $\mathrm{K}_{14}{ }^{+}$cells now sit directly on the basal lamina and express high levels of p63 protein. $\boldsymbol{F}$, Counts of normal $\left(\mathrm{p} 63^{+} / \mathrm{K} 14^{+}\right.$) and activated $\left(\mathrm{p} 63^{-} / \mathrm{K} 14^{+}\right) \mathrm{HBCs}$ in the recovering mouse 0 E. Asterisks indicate a statistically significant difference $\left({ }^{*} p<0.01,{ }^{* *} p<0.01\right.$, two-way ANOVA) by comparison with the previous time point for the cell type indicated. Likewise, normal 0 E is significantly different from 1 to $2 \mathrm{dpl} 0 \mathrm{OE}\left({ }^{\mathrm{tt}} p<0.01\right)$. Scale bars, $50 \mu \mathrm{m}$; insets, $10 \mu \mathrm{m}$.

\section{Discussion}

Our results demonstrate that $\mathrm{p} 63$ is a key player in the emergence of HBCs during development. The first definitive HBCs- $-\mathrm{p}^{+}{ }^{+}$/ $\mathrm{K}_{14}{ }^{+}$cells apposed to the basal lamina-appear in the mouse $\mathrm{OE}$ at E17.5. Their formation accelerates after birth, and the HBC layer reaches confluency by P10. These data closely match previous descriptions in the rat (Holbrook et al., 1995). Expression of p63 anticipates the appearance of definitive HBCs in the embryo; $\mathrm{p} 3^{+}$cells at this stage are slow-cycling, Sox $2^{+}, \mathrm{GBC}$-like, HBC progenitors, some of which are marked by Ascll at an early stage and many of which express Hes1 later (Fig. 11). Moreover, HBCs do not form in the absence of p63. We also show that the role of p63 in driving $\mathrm{HBC}$ differentiation in the OE appears to be conserved well into adult life. In the regenerating ventral rat OE, p63 expression recapitulates development by anticipating the reappearance of dormant HBCs. Conversely, we provide evidence suggesting that downregulation of p63 protein by mature HBCs is a hallmark of their activation to multipotency (Fig. 11).

\section{p63 is not necessary for development of a definitive} olfactory epithelium

To the best of our knowledge, our results are the first in which p63 is expressed by and required for basal cells of a tissue, but is dispensable for the generation of all other cell types. In contrast, loss of p63 expression elsewhere (specifically, the $\Delta \mathrm{Np} 63$ form, as in the $\mathrm{OE}$ ) prevents the formation of normal epithelia. For example, in addition to the disruption of the epidermis, the prostatic bud, the thymic anlage, and the breast buds do not form in p63null mice, nor is there squamous differentiation of the uterovaginal junction (Mills et al., 1999; Yang et al., 1999; Crum and McKeon, 2010). These developmental abnormalities are commonly attributed to a failure to form and/or maintain the basal cells of these tissues (Candi et al., 2007; McKeon and Melino, 2007; Su et al., 2009). Our results in the OE suggest that p63 is a prerequisite for the differentiation of a typical basal cell pheno-
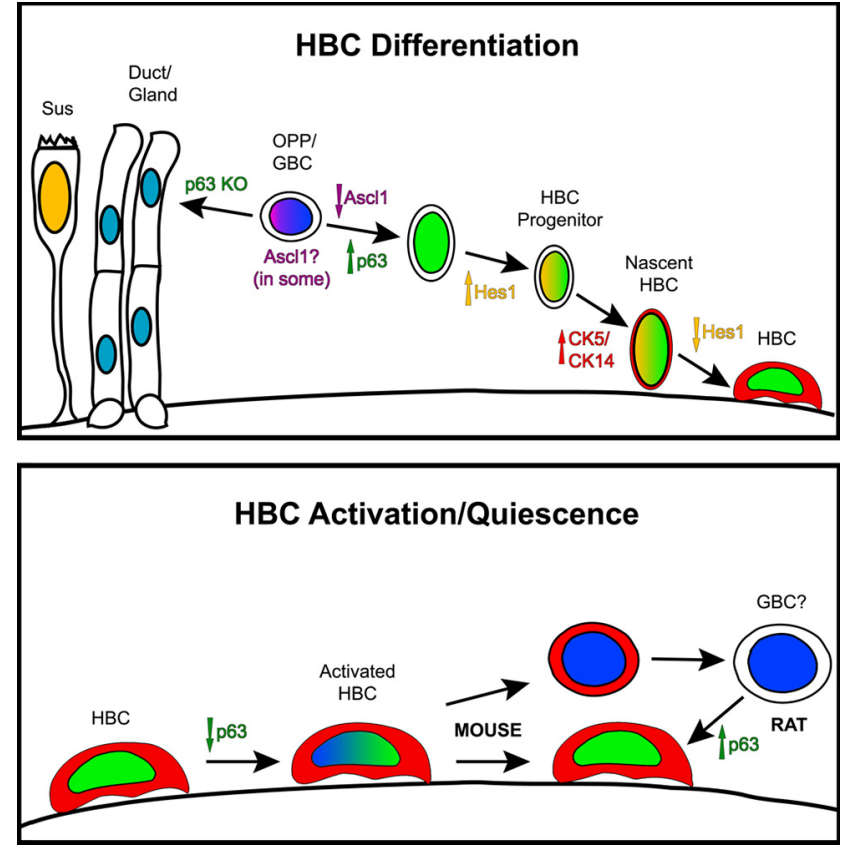

Figure 11. Schematic of $\mathrm{HBC}$ development and activation after injury. Top, HBCs develop from OPP/GBCs in the embryo. OPP/GBCs may transiently express Asc11 in some cases beforeturning on $\mathrm{p} 63$ and Hes 1 to become $\mathrm{HBC}$ progenitors. $\mathrm{HBC}$ progenitors then turn on expression of $\mathrm{K} 5 / \mathrm{K} 14$ and flatten against the basal lamina. Bottom, After severe injury to the $0 \mathrm{E}$, such as that caused by MeBr expression, HBCs downregulate $\mathrm{p} 63$ as they become multipotent progenitor cells.

type (flat cells directly apposed to the basal lamina with strong K5/14 and CD54 expression), but does not direct the generation of the entire tissue. In settings where cytokeratin-positive basal cells are obligate progenitors from which the tissue forms, loss of p63 aborts tissue development. However, the cytokeratinpositive HBCs of the OE (a pseudostratified epithelium) emerge 
later in development, after most of the architecture of the mature tissue has been assembled. While our data indicate that HBCs are not necessary for generating the $\mathrm{OE}$ de novo, we cannot exclude an essential contributory role for HBCs to the maintenance of the epithelium. It remains to be seen how loss of p63 and concurrent absence of HBCs affects the OE later in life. Do HBCs eventually form via an alternate pathway, as they do in the Ascl1 knock-out (see the next section)? Is the OE less stable in the absence of a backup progenitor population? Will the system exhibit functional/behavioral defects? Answers to these questions will require the creation of an OE-specific knock-out of the $p 63$ gene.

\section{HBCs develop from GBC-like progenitor cells}

We further characterized the $\mathrm{p} 63^{+} \mathrm{HBC}$ progenitors using a wide array of markers associated with OPPs and GBCs. In addition to a marker of multipotent GBCs and OPPs (Sox2), we found that HBC progenitor cells also express factors that are usually associated with lineage commitment, Ascl1 (commitment to neuronal lineage) in small number and Hes1 (commitment to Sus cell lineage) in a greater proportion. Moreover, the $\mathrm{p} 63^{+}$cells may be transitioning from Ascl1 expression to Hes1 expression (which persists in association with p63 and K14 during the first days of life). The substantial delay in p63 expression and HBC differentiation in Ascl1 KO OE might reflect a lineage whereby most HBCs develop from Ascl1 ${ }^{+}$precursor cells that transition to express p63 and Hes1. However, HBCs do emerge to some extent in Ascl1 KO OE, indicating that passage through an Ascl1 ${ }^{+}$progenitor is not an obligatory step in the differentiation of HBCs. We cannot rule out alternative pathways for HBC differentiation at present. First, $\mathrm{p}^{+}$progenitors may encompass distinct populations expressing Ascl1 versus Hes1 independently, rather than sequentially. Second, Ascl1 ${ }^{+} / \mathrm{p} 63^{+}$progenitors may give rise to cells other than HBCs. Extensive lineage tracing of $\mathrm{Ascl}^{+}$, $\mathrm{Hes}^{+}$, and $\mathrm{p} 63^{+}$cells will be essential to clarify the significance of the marker colocalization observed here. However, the data strongly indicate that $\mathrm{HBCs}$ arise from cells that closely resemble adult GBCs, consistent with past results (Schwob et al., 1995; Chen et al., 2004). Combined with our observations in the lesioned-recovering rat $\mathrm{OE}$, these data suggest a substantial flux among the basal stem/progenitor cell compartments.

\section{p63 regulates the cycling of progenitor cells from establishment to activation and the return to dormancy}

Past work suggests that HBCs function as a reserve progenitor/ stem cell population capable of replenishing all the cell types of the epithelium throughout postnatal life (Holbrook et al., 1995; Carter et al., 2004; Leung et al., 2007; Iwai et al., 2008). However, their multipotency remains largely dormant, i.e., they are incapable of engraftment following transplantation and give rise only to themselves, for the most part, unless activated by severe epithelial injury (Chen et al., 2004; Leung et al., 2007). Here we show that the sequential downregulation and then upregulation of p63 expression is tightly linked to the cycle of $\mathrm{HBC}$ activation and return to dormancy. Our findings in the MeBr-lesioned-recovering $\mathrm{OE}$ parallel observations in skin demonstrating that the transition from basal to suprabasal compartments is mediated by downregulation of p63 via miR-203 expression (Lena et al., 2008; Yi et al., 2008). Likewise, wound healing in humans is accompanied by a transient downregulation of $\mathrm{p} 63$ expression at the leading edge of the wound (Noszczyk and Majewski, 2001).

While the molecular mechanisms of the basal to suprabasal phenotypic shift are not fully understood, even in epidermis, p63 downregulation appears to be required (Yi et al., 2008). Direct targets of p63 in other epithelial tissues regulate cell adhesion, signal transduction components, and cell cycle regulators. Loss of expression of these molecules would allow basal cells to detach, migrate, and participate vigorously in regeneration and wound healing (Carroll et al., 2006; Yang et al., 2006; Thépot et al., 2010; Yalcin-Ozuysal et al., 2010). While the genes regulated by p63 in developing and adult HBCs are currently unknown, the potential downstream targets identified in other systems may be relevant to HBC dynamics as well. In this study we have looked at a number of genes already known to be direct targets of p63 including K5/14, CD54 (ICAM-1), and Hes1 (Kikuchi et al., 2004; Nguyen et al., 2006; Romano et al., 2009). The initial expression of Hes1 (a gene that is directly repressed by $\mathrm{p} 63$ in keratinocytes) (Nguyen et al., 2006) followed by its downregulation during HBC maturation illustrates that p63 targets can be dynamic even within a single tissue. Interestingly, we have found that another p63 target, Notch1, is expressed in adult HBCs (N. Schnittke, R. C. Krolewski, and J. E. Schwob, unpublished observations). Thus, identifying novel p63-dependent transcription programs throughout $\mathrm{OE}$ development and regeneration is a natural next step. An understanding of the mechanisms of HBC activation and return to quiescence will open a promising avenue for regulating the flow between the various stem/multipotent progenitor populations of the OE.

\section{Conclusion}

The OE is unique in the vigor with which epithelial progenitor cells repopulate neurons and non-neuronal cells for both tissue maintenance and regeneration. At least two multipotent progenitor cell populations underlie this ability. As such, the OE is an ideal system for uncovering dynamics of stem cell transitions that may apply elsewhere. We have identified p63 as a key transcription factor that may control the transition between stem cell types: p63 expression anticipates formation of the HBC reserve stem cell population, and p63 downregulation anticipates the activation of HBCs, seemingly back to GBCs. This pattern of $\mathrm{p} 63$ expression combined with our knock-out analysis suggests that p63 is playing a linchpin role in stem cell transitions and implicates it as a potential therapeutic target for inducing stem cell activation. The OE of anosmic humans is characterized by swathes of aneuronal OE that apparently lack GBCs but still retain HBCs (Holbrook et al., 2005). Similarly, aneuronal OE is observed in a transgenic mouse model in which OMP-driven misexpression of the SV40 T-antigen oncogene likely causes accelerated turnover (Largent et al., 1993). In these settings, HBCs have not been activated, and apparently cannot contribute to normal repair of the aneuronal tissue. Such activation might be accomplished by downregulating p63 in the OE of these patients.

\section{References}

Candi E, Rufini A, Terrinoni A, Dinsdale D, Ranalli M, Paradisi A, De Laurenzi V, Spagnoli LG, Catani MV, Ramadan S, Knight RA, Melino G (2006) Differential roles of 63 isoforms in epidermal development: selective genetic complementation in p63 null mice. Cell Death Differ 13:1037-1047.

Candi E, Dinsdale D, Rufini A, Salomoni P, Knight RA, Mueller M, Krammer PH, Melino G (2007) TAp63 and DeltaNp63 in cancer and epidermal development. Cell Cycle 6:274-285.

Carlén M, Meletis K, Göritz C, Darsalia V, Evergren E, Tanigaki K, Amendola M, Barnabé-Heider F, Yeung MS, Naldini L, Honjo T, Kokaia Z, Shupliakov O, Cassidy RM, Lindvall O, Frisén J (2009) Forebrain ependymal cells are Notch-dependent and generate neuroblasts and astrocytes after stroke. Nat Neurosci 12:259-267.

Carroll DK, Carroll JS, Leong CO, Cheng F, Brown M, Mills AA, Brugge JS, Ellisen LW (2006) p63 regulates an adhesion programme and cell survival in epithelial cells. Nat Cell Biol 8:551-561.

Carter LA, MacDonald JL, Roskams AJ (2004) Olfactory horizontal basal 
cells demonstrate a conserved multipotent progenitor phenotype. J Neurosci 24:5670-5683.

Cau E, Gradwohl G, Casarosa S, Kageyama R, Guillemot F (2000) Hes genes regulate sequential stages of neurogenesis in the olfactory epithelium. Development 127:2323-2332.

Cau E, Casarosa S, Guillemot F (2002) Mash1 and Ngn1 control distinct steps of determination and differentiation in the olfactory sensory neuron lineage. Development 129:1871-1880.

Chen X, Fang H, Schwob JE (2004) Multipotency of purified, transplanted globose basal cells in olfactory epithelium. J Comp Neurol 469:457-474.

Crum CP, McKeon FD (2010) p63 in epithelial survival, germ cell surveillance, and neoplasia. Annu Rev Pathol 5:349-371.

Delorme B, Nivet E, Gaillard J, Häupl T, Ringe J, Devèze A, Magnan J, Sohier J, Khrestchatisky M, Roman FS, Charbord P, Sensebé L, Layrolle P, Féron F (2010) The human nose harbors a niche of olfactory ectomesenchymal stem cells displaying neurogenic and osteogenic properties. Stem Cells Dev 19:853-866.

Ghioni P, Bolognese F, Duijf PH, Van Bokhoven H, Mantovani R, Guerrini L (2002) Complex transcriptional effects of $\mathrm{p} 63$ isoforms: identification of novel activation and repression domains. Mol Cell Biol 22:8659-8668.

Goldstein BJ, Fang H, Youngentob SL, Schwob JE (1998) Transplantation of multipotent progenitors from the adult olfactory epithelium. Neuroreport 9:1611-1617.

Graziadei PP, Graziadei GA (1979) Neurogenesis and neuron regeneration in the olfactory system of mammals. I. Morphological aspects of differentiation and structural organization of the olfactory sensory neurons. J Neurocytol 8:1-18.

Guo Z, Packard A, Krolewski RC, Harris MT, Manglapus GL, Schwob JE (2010) Expression of Pax6 and Sox2 in adult olfactory epithelium. J Comp Neurol 518:4395-4418.

Holbrook EH, Szumowski KE, Schwob JE (1995) An immunochemical, ultrastructural, and developmental characterization of the horizontal basal cells of rat olfactory epithelium. J Comp Neurol 363:129-146.

Holbrook EH, Leopold DA, Schwob JE (2005) Abnormalities of axon growth in human olfactory mucosa. Laryngoscope 115:2144-2154.

Huard JM, Youngentob SL, Goldstein BJ, Luskin MB, Schwob JE (1998) Adult olfactory epithelium contains multipotent progenitors that give rise to neurons and non-neural cells. J Comp Neurol 400:469-486.

Ito M, Yang Z, Andl T, Cui C, Kim N, Millar SE, Cotsarelis G (2007) Wntdependent de novo hair follicle regeneration in adult mouse skin after wounding. Nature 447:316-320.

Ito T, Udaka N, Yazawa T, Okudela K, Hayashi H, Sudo T, Guillemot F, Kageyama R, Kitamura H (2000) Basic helix-loop-helix transcription factors regulate the neuroendocrine differentiation of fetal mouse pulmonary epithelium. Development 127:3913-3921.

Iwai N, Zhou Z, Roop DR, Behringer RR (2008) Horizontal basal cells are multipotent progenitors in normal and injured adult olfactory epithelium. Stem Cells 26:1298-1306.

Jacobs WB, Govoni G, Ho D, Atwal JK, Barnabe-Heider F, Keyes WM, Mills AA, Miller FD, Kaplan DR (2005) p63 is an essential proapoptotic protein during neural development. Neuron 48:743-756.

Jang W, Youngentob SL, Schwob JE (2003) Globose basal cells are required for reconstitution of olfactory epithelium after methyl bromide lesion. J Comp Neurol 460:123-140.

Keyes WM, Pecoraro M, Aranda V, Vernersson-Lindahl E, Li W, Vogel H, Guo X, Garcia EL, Michurina TV, Enikolopov G, Muthuswamy SK, Mills AA (2011) DeltaNp63alpha is an oncogene that targets chromatin remodeler Lsh to drive skin stem cell proliferation and tumorigenesis. Cell Stem Cell 8:164-176.

Kikuchi T, Ichimiya S, Kojima T, Crisa L, Koshiba S, Tonooka A, Kondo N, Van Der Saag PT, Yokoyama S, Sato N (2004) Expression profiles and functional implications of p53-like transcription factors in thymic epithelial cell subtypes. Int Immunol 16:831-841.

Koster MI, Dai D, Marinari B, Sano Y, Costanzo A, Karin M, Roop DR (2007) p63 induces key target genes required for epidermal morphogenesis. Proc Natl Acad Sci U S A 104:3255-3260.

Kubilus JK, Linsenmayer TF (2010) Developmental corneal innervation: interactions between nerves and specialized apical corneal epithelial cells. Invest Ophthalmol Vis Sci 51:782-789.

Largent BL, Sosnowski RG, Reed RR (1993) Directed expression of an oncogene to the olfactory neuronal lineage in transgenic mice. J Neurosci 13:300-312.
Laurikkala J, Mikkola ML, James M, Tummers M, Mills AA, Thesleff I (2006) p63 regulates multiple signalling pathways required for ectodermal organogenesis and differentiation. Development 133:1553-1563.

Lena AM, Shalom-Feuerstein R, Rivetti di Val Cervo P, Aberdam D, Knight RA, Melino G, Candi E (2008) miR-203 represses 'stemness' by repressing DeltaNp63. Cell Death Differ 15:1187-1195.

Leung CT, Coulombe PA, Reed RR (2007) Contribution of olfactory neural stem cells to tissue maintenance and regeneration. Nat Neurosci 10:720-726.

Manglapus GL, Youngentob SL, Schwob JE (2004) Expression patterns of basic helix-loop-helix transcription factors define subsets of olfactory progenitor cells. J Comp Neurol 479:216-233.

McKeon F, Melino G (2007) Fog of war: the emerging p53 family. Cell Cycle 6:229-232

Mills AA, Zheng B, Wang XJ, Vogel H, Roop DR, Bradley A (1999) p63 is a p53 homologue required for limb and epidermal morphogenesis. Nature 398:708-713.

Nakamuta N, Kobayashi S (2007) Expression of p63 in the mouse ovary. J Reprod Dev 53:691-697.

Nguyen BC, Lefort K, Mandinova A, Antonini D, Devgan V, Della Gatta G, Koster MI, Zhang Z, Wang J, Tommasi di Vignano A, Kitajewski J, Chiorino G, Roop DR, Missero C, Dotto GP (2006) Cross-regulation between Notch and p63 in keratinocyte commitment to differentiation. Genes Dev 20:1028-1042.

Noszczyk BH, Majewski ST (2001) p63 expression during normal cutaneous wound healing in humans. Plast Reconstr Surg 108:1242-1247.

Romano RA, Birkaya B, Sinha S (2006) Defining the regulatory elements in the proximal promoter of DeltaNp63 in keratinocytes: potential roles for Sp1/Sp3, NF-Y, and p63. J Invest Dermatol 126:1469-1479.

Romano RA, Ortt K, Birkaya B, Smalley K, Sinha S (2009) An active role of the DeltaN isoform of p63 in regulating basal keratin genes K5 and K14 and directing epidermal cell fate. PLoS One 4:e5623.

Romano RA, Smalley K, Liu S, Sinha S (2010) Abnormal hair follicle development and altered cell fate of follicular keratinocytes in transgenic mice expressing DeltaNp63alpha. Development 137:1431-1439.

Schwob JE, Youngentob SL, Mezza RC (1995) Reconstitution of the rat olfactory epithelium after methyl bromide-induced lesion. J Comp Neurol 359:15-37.

Su X, Paris M, Gi YJ, Tsai KY, Cho MS, Lin YL, Biernaskie JA, Sinha S, Prives C, Pevny LH, Miller FD, Flores ER (2009) TAp63 prevents premature aging by promoting adult stem cell maintenance. Cell Stem Cell 5:64-75.

Suh EK, Yang A, Kettenbach A, Bamberger C, Michaelis AH, Zhu Z, Elvin JA, Bronson RT, Crum CP, McKeon F (2006) p63 protects the female germ line during meiotic arrest. Nature 444:624-628.

Suzuki Y, Takeda M (1991) Keratins in the developing olfactory epithelia. Brain Res Dev Brain Res 59:171-178.

Thépot A, Hautefeuille A, Cros MP, Abedi-Ardekani B, Pétré A, Damour O, Krutovskikh V, Hainaut P (2010) Intraepithelial p63-dependent expression of distinct components of cell adhesion complexes in normal esophageal mucosa and squamous cell carcinoma. Int J Cancer 127:2051-2062.

Tomé M, Lindsay SL, Riddell JS, Barnett SC (2009) Identification of nonepithelial multipotent cells in the embryonic olfactory mucosa. Stem Cells 27:2196-2208.

Wildner H, Müller T, Cho SH, Bröhl D, Cepko CL, Guillemot F, Birchmeier C (2006) dILA neurons in the dorsal spinal cord are the product of terminal and non-terminal asymmetric progenitor cell divisions, and require Mash1 for their development. Development 133:2105-2113.

Yalcin-Ozuysal O, Fiche M, Guitierrez M, Wagner KU, Raffoul W, Brisken C (2010) Antagonistic roles of Notch and p63 in controlling mammary epithelial cell fates. Cell Death Differ 17:1600-1612.

Yang A, Kaghad M, Wang Y, Gillett E, Fleming MD, Dötsch V, Andrews NC, Caput D, McKeon F (1998) p63, a p53 homolog at 3q27-29, encodes multiple products with transactivating, death-inducing, and dominantnegative activities. Mol Cell 2:305-316.

Yang A, Schweitzer R, Sun D, Kaghad M, Walker N, Bronson RT, Tabin C, Sharpe A, Caput D, Crum C, McKeon F (1999) p63 is essential for regenerative proliferation in limb, craniofacial and epithelial development. Nature 398:714-718.

Yang A, Zhu Z, Kapranov P, McKeon F, Church GM, Gingeras TR, Struhl K (2006) Relationships between $\mathrm{p} 63$ binding, DNA sequence, transcription activity, and biological function in human cells. Mol Cell 24:593-602.

Yi R, Poy MN, Stoffel M, Fuchs E (2008) A skin microRNA promotes differentiation by repressing 'stemness'. Nature 452:225-229. 